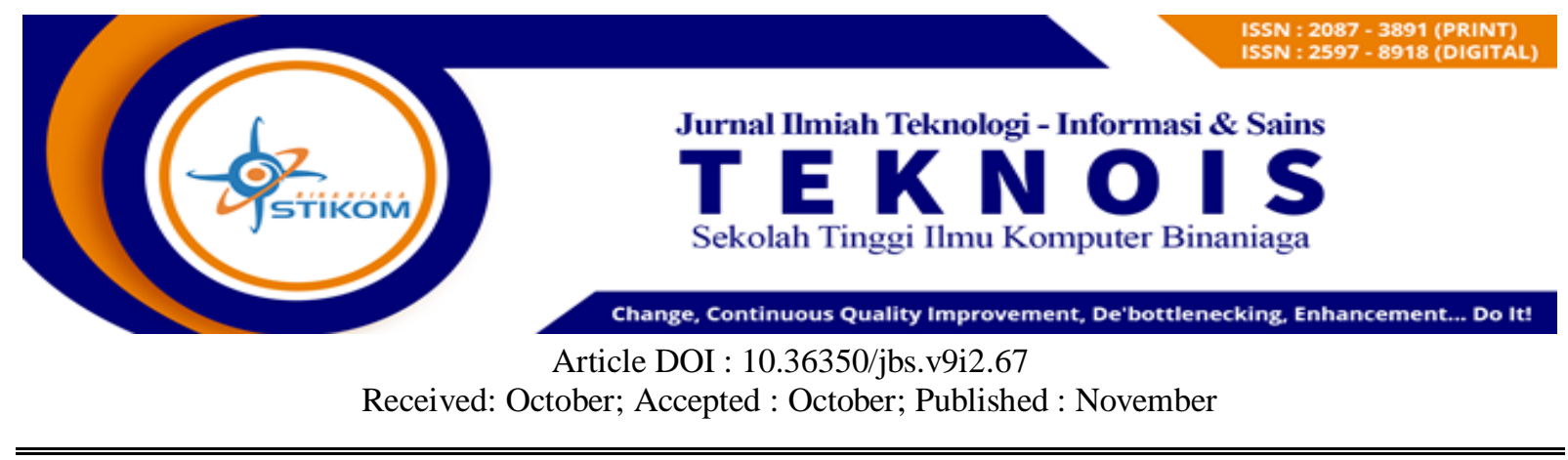

\title{
Penentuan kenaikan level pada karyawan dengan penerapan metode profile matching
}

\author{
Lis Utari ${ }^{1 *}$, Ika Merina ${ }^{2}$ \\ ${ }^{1}$ Teknik Informatika/STIKOM Binaniga \\ Email: lisutari@stikombinaniaga.ac.id \\ ${ }^{2}$ Sistem Informasi/STIKOM Binaniga \\ Email: ikamerina94@gmail.com
}

\begin{abstract}
PT Infomedia Solusi Humanika is an outsourcing company that works with PT. Telkom Indonesia, electing employees who will go up / level, but a few months later the level obtained by the employee dropped or decreased level because that will be held re-election for all employees in the Fulfillment division using the Profile Matching calculation (Matching Profile). In the Profile Matching Method, there is a Gap, that is, if the employee's value approaches the value of the gap, the employee's opportunity to level up is even greater. The criteria used for evaluating employee performance are Personal Data criteria, Job Performance criteria, Job Attitude criteria, and Behavior criteria. After analyzing using the Profile Matching method for 28 employees of PT. Infomedia Humanika Solutions obtained rankings and known to be the most superior employee among other employees. For data analysis calculations used Linear Regression analysis. The results of the analysis found that the criteria that had the most influence on employee ranking were the Job Performance criteria and the least influential criteria were the Work Attitude criteria.
\end{abstract}

Keywords: Profile Matching; Linear Regression.

\section{ABSTRAK}

PT Infomedia Solusi Humanika adalah perusahaan Outsourcing yang bekerja sama dengan PT. Telkom Indonesia, mengadakan pemilihan karyawan yang akan naik tingkat/level, namun beberapa bulan kemudian level yang di dapatkan oleh karyawan tersebut turun atau mengalami penurunan level, karena itu akan diadakan pemilihan ulang kembali bagi seluruh karyawan di divisi Fullfillment dengan menggunakan perhitungan Profile Matching (Pencocokan Profil). Pada Metode Profile Matching terdapat Gap, yaitu apabila nilai karyawan semakin mendekati nilai gap maka peluang karyawan untuk naik level semakin besar. Kriteria yang digunakan untuk penilaian kinerja karyawan adalah kriteria Data Pribadi, kriteria Prestasi Kerja, kriteria Sikap Kerja dan kriteria Perilaku. Setelah melakukan analisa menggunakan metode Profile Matching terhadap 28 karyawan PT. Infomedia Solusi Humanika diperoleh hasil rangking dan diketahui karyawan yang paling unggul diantara karyawan yang lain. Untuk perhitungan analisa data digunakan analisis Regresi Linier. Hasil dari analisis tersebut diperoleh adanya kriteria yang paling berpengaruh terhadap rangking karyawan yaitu kriteria Prestasi Kerja dan Kriteria yang paling sedikit berpengaruh adalah kriteria Sikap Kerja.

Keywords: Profile Matching; Regresi Linear. 


\section{A. PENDAHULUAN}

Sumber Daya Manusia (Kasmir (2018:6), merupakan proses pengelolaan manusia, melalui perencanaan, rekrutmen, seleksi, pelatihan, pengembangan, pemberian kompensasi, karier, keselamatan, dan kesehatan serta menjadi hubungan kerja guna mencapai tujuan perusahaan dan peningkatan kesejahteraan. Agar tercapai tingkat efektifitas dan efisiensi yang diinginkan, maka dalam perusahaan tersebut harus memiliki sistem kerja yang baik atau memiliki kinerja yang baik.

Menurut Dessler (2000:41), kinerja merupakan prestasi kerja, yaitu perbandingan antara hasil kerja dengan standar yang ditetapkan. Dengan demikian kinerja difokuskan pada hasil kerjanya. Menurut Robbins (2003: 226), kinerja adalah akumulasi hasil akhir semua proses dan kegiatan kerja organisasi.

Menurut As'ad (1995:93) gaji sebenarnya juga upah hanya sedikit perbedaanya, gaji adalah banyaknya uang yang diterima dan sudah pasti dan waktunya selalu tepat, misalnya setiap awal bulan, seorang karyawan akan menerima sejumlah uang yang disebut gaji, sedangkan upah adalah banyaknya uang yang diterimanya tidak selalu sama atau pasti dan waktunyapun tidak selalu tepat.

Keberhasilan sebuah instansi atau organisasi tentu saja tak lepas dari peran serta karyawan sebagai SDM yang menjalankan berbagai macam aktifitas dalam bekerja. Penyeleksian karyawan untuk menentukan kenaikan level / gaji masih di lakukan secara subjektif sehingga menimbulkan kecemburuan sosial dengan karyawan yang lain. Untuk membantu para manajer dalam memilih karyawan yang akan di promosikan maka perlu adanya pendukung keputusan dalam menentukan karyawan yang layak untuk kenaikan level/ gaji. Kenaikan level / gaji karyawan di PT. Infomedia Solusi Humanika terjadi penurunan, sehingga Manajer PT. Telkom Indonesia dan penanggung jawab karyawan outsourching PT. Infomedia Solusi Humanika melakukan penyeleksian ulang berdasarkan kriteria yang telah di tentukan yaitu, data pribadi, prestasi kerja, sikap kerja, dan perilaku. Metode atau cara yang digunakan untuk pengambilan keputusan adalah dengan menggunakan metode Profile Matching (Pencocokan Profil). Menurut Kusrini (2007), Metode Profile Matching (Pencocokan Profil) adalah metode yang sering digunakan sebagai mekanisme dalam pengambilan keputusan dengan mengasumsikan bahwa terdapat tingkat variabel prediktor yang ideal harus dipenuhi oleh subyek yang diteliti. Dalam proses Profile Matching secara garis besar merupakan proses membandingkan antara nilai data aktual dari suatu profil yang akan di nilai dengan nilai profil yang diharapkan, sehingga dapat diketahui perbedaan kompetensinya (disebut juga gap). Semakin kecil gap yang dihasilkan maka bobot nilainya semakin besar.

\section{B. METODE}

\section{Profile Matching (Pencocokan Profil)}

Pencocokan Profil (Profile Matching) adalah mekanisme pengambilan keputusan dengan mengasumsikan bahwa terdapat variabel prediktor yang ideal yang harus dimiliki oleh pegawai. Dalam pencocokan profil, dilakukan identifikasi terhadap kelompok karyawan yang baik maupun buruk. Para karyawan dalam kelompok tersebut diukur menggunakan beberapa kriteria penilaian. Jika pelaksana yang baik memperoleh skor yang berbeda dari pelaksana yang buruk atau sebuah karakteristik, maka variabel tersebut berfaedah untuk memilih pelaksana yang baik. Begitu beberapa variabel yang membedakan antara pelaksana-pelaksana yang baik dan buruk telah teridentifikasi. Dalam pencocokan profil, pegawai yang mendekati profil ideal ialah seorang pegawai yang berhasil (Kusrini: 2007). Tahap berikutnya perbandingan dilakukan antara kemampuan individu dengan kualifikasi yang telah ditetapkan sehingga didapatkan gap dimana semakin kecil nilai yang didapatkan maka bobot nilai semakin besar

Core Factor dan Secondary Factor menjadi perhitungan berikutnya dengan cara memberikan besaran presentase untuk kedua faktor tersebut. Dalam penelitian ini Core factor diberikan sebanyak 60\% dan 40\% untuk Secondary Factor. Pemberian Rangking adalah proses 
perhitungan hasil akhir untuk menentukan karyawan yang akan naik level dalam pengambilan keputusan. Metode Profile Matching memiliki beberapa tahapan yang harus dilakukan. Berikut adalah kriteria-kriteria yang digunakan yaitu:

a. Kriteria Data Pribadi. Kriteria data pribadi adalah data pendukung yang bersumber dari biodata karyawan. Kriteria tersebut memiliki 3 faktor, yaitu:
1) Jabatan
2) Pendidikan
3) Lama Bekerja

b. Kriteria Prestasi Kerja. Kriteria tersebut memiliki 5 faktor, yaitu:

1) Absensi. Keberadaan atau bukti kehadiran karyawan pada saat masuk kerja sampai dengan pulang kerja. (Core Factor).

2) Target Kerja. Karyawan harus mencapai target dalam bekerja atau target tertinggi di antara karyawan yang lain untuk kenaikan level (Core Factor)

3) Konsentrasi Kerja. Karyawan harus berkonsentrasi dalam bekerja (Secondary Factor).

4) Pengetahuan Tentang Kerja. Karyawan mempunyai pengetahuan dalam bidang tertentu sesuai dengan bidang atau jabatanya masing- masing. (Core Factor)

5) Gagasan Ide. Karyawan memiliki ide yang sangat luas untuk kemajuan dalam bekerja. (Secondary Factor).

c. Kriteria Sikap Kerja. Kriteria tersebut memiliki 5 faktor, yaitu:

1) Kepemimpinan. Kemampuan menggerakan tim kerja untuk mencapai kinerja yang tinggi. (Secondary Factor).

2) Motivasi. Memiliki motivasi dalam bekerja, semangat dalam bekerja (Core Factor).

3) Sistematik Kerja. Setiap tugas yang dikerjakan oleh karyawan sesuai urutan yang sistematik (Core Factor)

4) Kerjasama. Selalu mampu bekerja sama dengan rekan kerja, atasan baik di dalam maupun di luar organisasi. (Secondary Factor)

5) Teliti dan Tanggung Jawab. Memiliki tanggung jawab dan ketelitian atas kewajiban dan tugas dari masing-masing pekerjaannya. (Core Factor).

d. Kriteria Perilaku. Kriteria tersebut memiliki 5 faktor, yaitu:

1) Disiplin. Merupakan usaha karyawan untuk menjalankan aktivitas kerjanya secara sungguh-sungguh. (Core Factor)

2) Komunikasi. Marsan (2011:24) mengatakan, komunikasi adalah proses penyampaian pesan dari pengirim (sender) kepada penerima (receiver atau audience). Memiliki komunikasi yang baik dengan rekan kerja maupun atasan. (Secondary Factor)

3) Loyalitas. Loyalitas merupakan kesetiaan karyawan untuk tetap bekerja dan membela perusahaan. (Secondary Factor)

4) Taat Aturan. Karyawan harus mematuhi segala peraturan yang telah ditetapkan, misalnya dalam hal safety, dan karyawan patuh kepada atasan. (Core Factor)

5) Percaya Diri. Memiliki percaya diri yang sangat tinngi dalam hal bekerja maupun dalam menyampaikan gagasan-gagasan ide (Secondary Factor). 
2. Pemetaan Gap Kompetensi

Gap merupakan suatu alat yang digunakan untuk mengevaluasi kinerja. Metode ini merupakan salah satu metode yang umum digunakan dalam pengelolaan manajemen suatu lembaga. Secara harfiah kata "gap" mengindikasikan adanya suatu perbedaan (disparity) antara satu hal dengan hal lainnya. Gap yang dimaksud adalah beda antara profil jabatan dengan profil karyawan atau dapat ditunjukkan pada rumus:

\section{Gap = Profil Pegawai - Profil Jabatan}

Sedangkan untuk pengumpulan gap-gap yang terjadi itu sendiri pada tiap aspeknya mempunyai perhitungan yang berbeda-beda (Kusrini, 2007).

3. Perhitungan Core Factor, Secondary Factor, Nilai Total dan Nilai Rangking

Setiap aspek dikelompokkan menjadi 2 kelompok, yaitu kelompok core factor dan secondary factor (Kusrini, 2007):

\section{a) Core Factor}

Merupakan kriteria (kompetensi) yang paling penting atau menonjol atau paling dibutuhkan oleh suatu penilaian yang diharapkan dapat memperoleh hasil yang optimal.

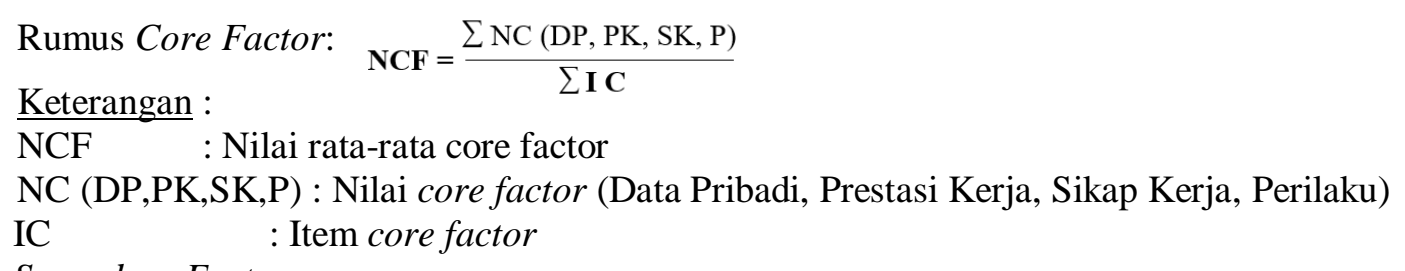

b) Secondary Factor

Merupakan item-item selain yang ada pada core factor, atau dengan kata lain merupakan faktor pendukung yang kurang dibutuhkan oleh suatu penilaian.

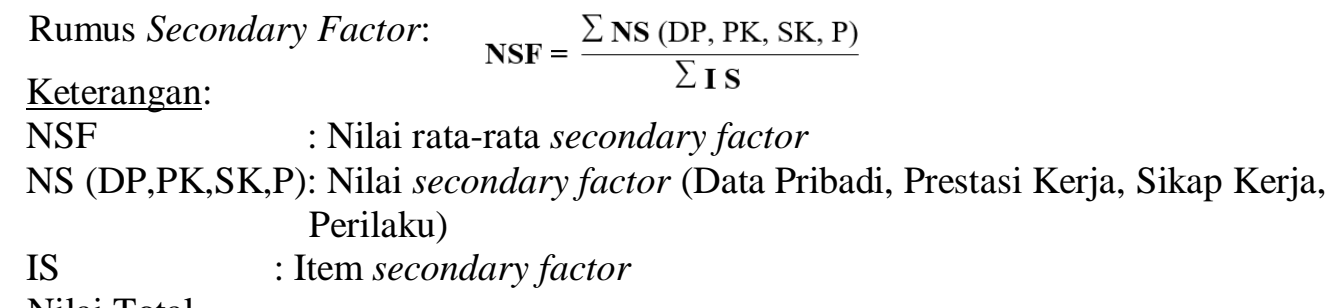

c) Nilai Total

Dari hasil perhitungan setiap aspek rumus, berikutnya dihitung nilai total berdasarkan presentase dari core dan secondary yang diperkirakan berpengaruh terhadap kinerja tiaptiap profil. Perhitungan nilai total dapat dilihat pada rumus (Kusrini, 2007):

$\mathrm{N}=(\mathrm{x}) \%$.NCF(DP,PK,SK,P) + (x)\%.NSF(DP,PK,SK,P)

Keterangan:

NCF(DP,PK,SK,P) : Nilai rata-rata core factor (Data Pribadi, Prestasi Kerja, Sikap Kerja, Perilaku)

NSF(DP,PK,SK,P) : Nilai rata-rata secondary factor (Data Pribadi, Prestasi Kerja, Sikap Kerja, Perilaku)

N(DP,PK,SK,P) : Nilai total dari kriteria Data Pribadi, Prestasi Kerja,Sikap Kerja, dan Perilaku

(x)\% : Nilai persen yang diinputkan

d) Nilai Rangking

Hasil akhir dari proses pencocokan profil adalah ranking dari kandidat yang diajukan untuk mengisi jabatan tertentu. Penentuan ranking mengacu pada hasil perhitungan tertentu. Sesuai dengan rumus (Kusrini, 2007):

$$
\text { Ranking }=(x) \% . N D P+(x) \% . N P K+(x) \% . N S K+(x) \% . N P
$$

Keterangan:

NDP : Nilai Data Pribadi; $\quad$ NPK : Nilai Prestasi Kerja; $\quad$ NSK : Nilai Sikap Kerja

NP : Nilai Perilaku; $\quad$ (x)\% : Nilai Persen yang diinputkan

(C)2019 Teknois : Jurnal IImiah Teknologi Informasi dan Sains. Copyrights All rights reserved 
Volume 9 Number 2 November 2019 Page. 65-78

Journal Homepage : http://teknois.stikombinaniaga.ac.id/index.php/JBS

DOI Link : http://doi.org/10.36350/jbs.v9i2

\section{Pembobotan}

Nilai pembobotan dari hasil gap dapat diukur menggunakan tabel dibawah ini:

Tabel 1. Bobot Nilai Gap

\begin{tabular}{|c|c|l|}
\hline Selisih & Bobot Nilai & \multicolumn{1}{|c|}{ Keterangan } \\
\hline 0 & 5 & $\begin{array}{l}\text { Tidak ada selisih (kompetensi sesuai dengan } \\
\text { yang di butuhkan) }\end{array}$ \\
\hline 1 & 4,5 & Kompetensi individu kelebihan 1 tingkat \\
\hline-1 & 4 & Kompetensi individu kekurangan 1 tingkat \\
\hline 2 & 3,5 & Kompetensi individu kelebihan 2 tingkat \\
\hline-2 & 3 & Kompetensi individu kekurangan 2 tingkat \\
\hline 3 & 2,5 & Kompetensi individu kelebihan 3 tingkat \\
\hline-3 & 2 & Kompetensi individu kekurangan 3 tingkat \\
\hline 4 & 1,5 & Kompetensi individu kelebihan 4 tingkat \\
\hline-4 & 1 & Kompetensi individu kekurangan 4 tingkat \\
\hline
\end{tabular}

\section{HASIL DAN PEMBAHASAN}

1. Hasil

Hasil akhir dari proses Profile Matching adalah ranking dari karyawan yang akan diangkat untuk naik level. Perhitungan ranking bisa ditunjukkan dengan rumus sebagai berikut:

Ranking $=(30 \% \cdot \mathrm{NDP})+(30 \% \cdot \mathrm{NPK})+(20 \% \cdot \mathrm{NSK})+(20 \% \cdot \mathrm{NP})$.

Hasil Ranking dapat dilihat pada tabel dibawah ini:

Tabel 2. Perhitungan Penentuan Ranking

\begin{tabular}{|c|l|c|c|c|c|c|}
\hline No & \multicolumn{1}{|c|}{ Nama } & NDP & NPK & NSK & NP & Ranking \\
\hline 1 & Ade Apriliani & 3,9 & 4,4 & 4,2 & 4,564 & 4,243 \\
\hline 2 & Any Kustyanti & 3,3 & 4,196 & 4,398 & 4,2 & 3,968 \\
\hline 3 & Bayu Arby & 4,7 & 4,398 & 4,398 & 4,5 & 4,509 \\
\hline 4 & Bidar Sulistyawati & 4,2 & 3,798 & 3,2 & 4,564 & 3,952 \\
\hline 5 & Cici Maryati & 3,9 & 3,898 & 3,898 & 4,032 & 3,925 \\
\hline 6 & Citra Dewi & 4,4 & 3,4 & 4,2 & 4,2 & 4,020 \\
\hline 7 & Danty Indriastuti & 4,2 & 2,996 & 3,7 & 4,5 & 3,799 \\
\hline 8 & Dolok Parlindungan & 4,5 & 4,498 & 4,198 & 4,564 & 4,452 \\
\hline 9 & Fajar Febriansyah & 5 & 4,598 & 4,398 & 4,632 & 4,685 \\
\hline 10 & Gloria Fharida & 4,5 & 4,398 & 4,398 & 4,632 & 4,475 \\
\hline 11 & Harist & 4,4 & 3,6 & 4,3 & 3,964 & 4,053 \\
\hline 12 & Hasanudin & 4,5 & 3,998 & 4,398 & 4,432 & 4,315 \\
\hline 13 & Ika Merina & 4,4 & 4,2 & 4,3 & 3,832 & 4,206 \\
\hline 14 & Iqra Ali & 4,4 & 4,2 & 4,3 & 4,2 & 4,280 \\
\hline
\end{tabular}

\begin{tabular}{|c|l|c|c|c|c|c|}
\hline No & \multicolumn{1}{|c|}{ Nama } & NDP & NPK & NSK & NP & Ranking \\
\hline 15 & Joddy Putranto & 4,5 & 4 & 4,3 & 4,432 & 4,296 \\
\hline 16 & Joko Sayful & 4,7 & 4,4 & 4,2 & 3,8 & 4,330 \\
\hline 17 & Layla Julia & 4,4 & 3,798 & 4,498 & 4,132 & 4,185 \\
\hline 18 & Liana Dessy & 3,9 & 4 & 4,1 & 3,964 & 3,983 \\
\hline 19 & M. Abid Mutaki & 3,9 & 3,998 & 4,498 & 3,9 & 4,049 \\
\hline 20 & Nyekarini & 3,5 & 4,598 & 4,3 & 4,064 & 4,102 \\
\hline 21 & Piyan Pirdaus & 3,5 & 3,798 & 3,6 & 3 & 3,509 \\
\hline 22 & Rizal Khoirul & 4,4 & 3,796 & 4,3 & 4,064 & 4,132 \\
\hline 23 & Sandi Kurniadi & 4,7 & 4,198 & 3,6 & 3,964 & 4,182 \\
\hline 24 & Sumiyanto & 3,5 & 4,398 & 3,998 & 3,732 & 3,915 \\
\hline 25 & Waidah Nur Intan & 4,5 & 4,4 & 4,2 & 3,964 & 4,303 \\
\hline 26 & Windha Receiviana & 3,9 & 3,8 & 4,398 & 4,264 & 4,042 \\
\hline 27 & Yogie Kusuma & 4,5 & 4,196 & 4,3 & 4,132 & 4,295 \\
\hline 28 & Zakaria Prasetyo & 4,5 & 3,4 & 3,998 & 4,264 & 4,022 \\
\hline
\end{tabular}

Hasil akhir dari perhitungan kinerja analisa di atas dengan menggunakan metode Profile Matching (Pencocokan Profil) adalah sebagai berikut:

Tabel 3. Hasil Penilaian Kinerja

\begin{tabular}{|c|l|c|}
\hline No & \multicolumn{1}{|c|}{ Nama } & Ranking \\
\hline 1 & Fajar Febriansyah & 4,685 \\
\hline 2 & Bayu Arby & 4,509 \\
\hline 3 & Gloria Fharida & 4,475 \\
\hline 4 & Dolok Parlindungan & 4,452 \\
\hline 5 & Joko Sayful & 4,330 \\
\hline 6 & Hasanudin & 4,315 \\
\hline 7 & Waidah Nur Intan & 4,303 \\
\hline 8 & Joddy Putranto & 4,296 \\
\hline 9 & Yogie Kusuma & 4,295 \\
\hline 10 & Iqra Ali & 4,280 \\
\hline 11 & Ade Apriliani & 4,243 \\
\hline 12 & Ika Merina & 4,206 \\
\hline 13 & Layla Julia & 4,185 \\
\hline 14 & Sandi Kurniadi & 4,182 \\
\hline
\end{tabular}

\begin{tabular}{|c|l|c|}
\hline No & \multicolumn{1}{|c|}{ Nama } & Ranking \\
\hline 15 & Rizal Khoirul & 4,132 \\
\hline 16 & Nyekarini & 4,102 \\
\hline 17 & Harist & 4,053 \\
\hline 18 & M. Abid Mutaki & 4,049 \\
\hline 19 & Windha Receiviana & 4,042 \\
\hline 20 & Zakaria Prasetyo & 4,022 \\
\hline 21 & Citra Dewi & 4,020 \\
\hline 22 & Liana Dessy & 3,983 \\
\hline 23 & Any Kustyanti & 3,968 \\
\hline 24 & Bidar Sulistyawati & 3,952 \\
\hline 25 & Cici Maryati & 3,925 \\
\hline 26 & Sumiyanto & 3,915 \\
\hline 27 & Danty Indriastuti & 3,799 \\
\hline 28 & Piyan Pirdaus & 3,509 \\
\hline
\end{tabular}




\section{Pembahasan}

Tahap-Tahap Penilaian karyawan dengan metode Profile Matching adalah sebagai berikut:

a) Penentuan Rangking Kandidat

Kriteria yang diperlukan dalam penilaian karyawan untuk menentukan kenaikan level karyawan adalah sebagai berikut: Kriteria Data Pribadi, Kriteria Prestasi Kerja, Kriteria Sikap Kerja, Kriteria Perilaku.

Kemudian kriteria-kriteria ini dibagi menjadi dua bagian untuk proses perhitungannya yaitu: Core Factor (Faktor Utama) yang merupakan kriteria (kompetensi) yang paling penting atau menonjol atau paling dibutuhkan oleh suatu penilaian yang diharapkan dapat memperoleh hasil yang optimal dan Secondary Factor (Faktor Pendukung) yang merupakan item-item selain yang ada pada core factor, atau dengan kata lain merupakan faktor pendukung yang kurang dibutuhkan oleh suatu penilaian.

b) Kriteria-Kriteria Pemetaan Gap Kompetensi

Proses penentuan bobot tiap kriteria akan melalui proses pendeskripsian dari pihak perusahaan. Seperti tabel dibawah ini adalah bobot profil karyawan untuk naik level, yang pembobotan tersebut dilakukan oleh kepala perusahaan dari masing- masing jabatan.

Tabel 4. Penentuan Bobot Nilai Kriteria

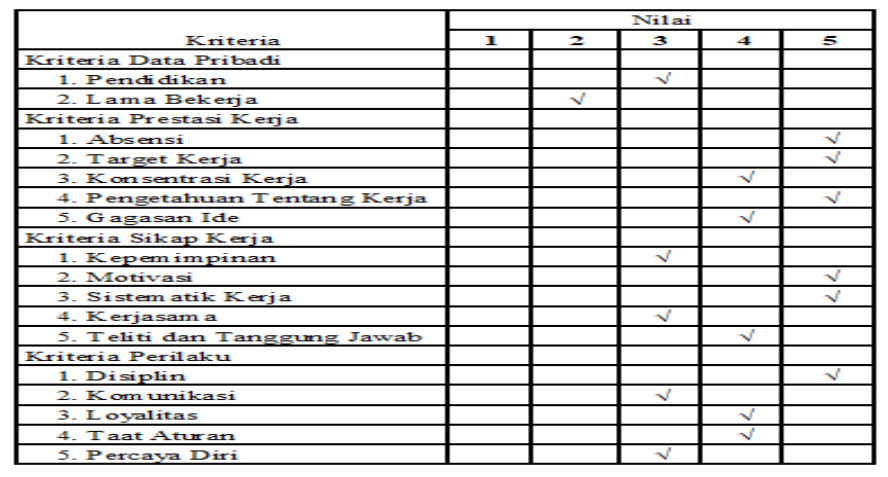

c) Proses Perhitungan Pemetaan Gap Kompetensi

Gap yang dimaksud adalah beda antara profil jabatan dengan profil karyawan atau dapat ditunjukkan pada rumus: Gap $=$ Profil Pegawai - Profil Jabatan .

Sedangkan untuk pengumpulan gap-gap yang terjadi itu sendiri pada tiap aspeknya mempunyai perhitungan yang berbeda-beda (Kusrini, 2007).

1) Kriteria Data Pribadi.

Pada Kriteria ini dilakukan proses perhitungan gap antara profil karyawan dan profil jabatan. Profil Ideal diperoleh dari tabel penentuan bobot nilai dimana pendidikan bernilai 3 dan lama bekerja bernilai 2. Untuk data pemetaan gap diperoleh dari masing-masing nilai profil karyawan dikurangi profil ideal.

Tabel 5. Tabel Data Pribadi

\begin{tabular}{|c|l|c|c|}
\hline No & \multicolumn{1}{|c|}{ Nama } & Pendidikan & $\begin{array}{c}\text { Lama } \\
\text { Bekerja }\end{array}$ \\
\hline 1 & Ade Apriliani & 4 & 4 \\
\hline 2 & Any Kustyanti & 4 & 5 \\
\hline 3 & Bayu Arby & 3 & 3 \\
\hline 4 & Bidar Sulistyawati & 4 & 1 \\
\hline 5 & Cici Maryati & 4 & 4 \\
\hline 6 & Citra Dewi & 3 & 1 \\
\hline 7 & Danty Indriastuti & 4 & 1 \\
\hline 8 & Dolok Parlindungan & 4 & 3 \\
\hline 9 & Fajar Febriansyah & 3 & 2 \\
\hline 10 & Gloria Fharida & 4 & 3 \\
\hline 11 & Harist & 3 & 1 \\
\hline 12 & Hasanudin & 4 & 3 \\
\hline 13 & Ika Merina & 3 & 1 \\
\hline 14 & Iqra Ali & 3 & 1 \\
\hline
\end{tabular}

\begin{tabular}{|c|l|c|c|}
\hline No & \multicolumn{1}{|c|}{ Nama } & Pendidikan & $\begin{array}{c}\text { Lama } \\
\text { Bekerja }\end{array}$ \\
\hline 15 & Joddy Putranto & 4 & 3 \\
\hline 16 & Joko Sayful & 3 & 3 \\
\hline 17 & Layla Julia & 3 & 1 \\
\hline 18 & Liana Dessy & 4 & 4 \\
\hline 19 & M. Abid & 4 & 4 \\
\hline 20 & Nyekarini & 3 & 5 \\
\hline 21 & Piyan Pirdaus & 1 & 4 \\
\hline 22 & Rizal Khoirul & 3 & 1 \\
\hline 23 & Sandi Kurniadi & 3 & 3 \\
\hline 24 & Sumiyanto & 3 & 5 \\
\hline 25 & Waidah Nur Intan & 4 & 3 \\
\hline 26 & Windha Receiviana & 4 & 4 \\
\hline 27 & Yogie Kusum a & 3 & 5 \\
\hline 28 & Zakaria Prasetyo & 4 & 3 \\
\hline Profil Ideal & 3 & 2 \\
\hline
\end{tabular}


Volume 9 Number 2 November 2019 Page. 65-78

Journal Homepage : http://teknois.stikombinaniaga.ac.id/index.php/JBS

DOI Link : http://doi.org/10.36350/jbs.v9i2

Tabel 6. Tabel Pemetaan Gap Data Pribadi

\begin{tabular}{|c|l|c|c|}
\hline No & \multicolumn{1}{|c|}{ Nama } & Pendidikan & $\begin{array}{c}\text { Lama } \\
\text { Bekerja }\end{array}$ \\
\hline 1 & Ade Apriliani & 1 & 2 \\
\hline 2 & Any Kustyanti & 1 & 3 \\
\hline 3 & Bayu Arby & 0 & 0 \\
\hline 4 & Bidar Sulistyawati & 1 & -1 \\
\hline 5 & Cici Maryati & 1 & 1 \\
\hline 6 & Citra Dewi & 0 & -1 \\
\hline 7 & Danty Indriastuti & 1 & -1 \\
\hline 8 & Dolok Parlindungan & 1 & 1 \\
\hline 9 & Fajar Febriansyah & 0 & 0 \\
\hline 10 & Gloria Fharida & 1 & 1 \\
\hline 11 & Harist & 0 & -1 \\
\hline 12 & Ha sanudin & 1 & 1 \\
\hline 13 & Ika Merina & 0 & -1 \\
\hline 14 & Iqra Ali & 0 & -1 \\
\hline
\end{tabular}

\begin{tabular}{|c|l|c|c|}
\hline No & \multicolumn{1}{|c|}{ Nama } & Pendidikan & $\begin{array}{c}\text { L am a } \\
\text { Bekeria }\end{array}$ \\
\hline 15 & Joddy Putranto & 1 & 1 \\
\hline 16 & Joko Sayful & 0 & 1 \\
\hline 17 & Layla Julia & 0 & -1 \\
\hline 18 & Liana Dessy & 1 & 2 \\
\hline 19 & M. Abid & 1 & 2 \\
\hline 20 & Nyekarini & 0 & 3 \\
\hline 21 & Piyan Pirdaus & -2 & 2 \\
\hline 22 & Rizal Khoirul & 0 & -1 \\
\hline 23 & Sandi Kurniadi & 0 & 1 \\
\hline 24 & Sumiyanto & 0 & 3 \\
\hline 25 & Waidah Nur Intan & 1 & 1 \\
\hline 26 & Windha Receiviana & 1 & 2 \\
\hline 27 & Yogie Kusuma & 0 & 3 \\
\hline 28 & Zakaria Prasetyo & 1 & 1 \\
\hline
\end{tabular}

2) Kriteria Prestasi Kerja

Pada Kriteria ini dilakukan proses perhitungan gap antara profil karyawan dan profil jabatan. Profil Ideal diperoleh dari tabel penentuan bobot nilai dimana absensi bernilai 5, target kerja bernilai 5, konsentrasi kerja bernilai 4, pengetahuan tentang kerja bernilai 5 , gagasan ide bernilai 4 . Untuk data pemetaan gap diperoleh dari masing-masing nilai profil karyawan dikurangi profil ideal.

Tabel 7. Tabel Data Prestasi Kerja

\begin{tabular}{|c|l|c|c|c|c|c|}
\hline No & \multicolumn{1}{|c|}{ Nama } & Absensi & TK & KK & PTK & GI \\
\hline 1 & Ade Apriliani & 4 & 4 & 4 & 4 & 4 \\
\hline 2 & Any Kustyanti & 4 & 3 & 4 & 4 & 4 \\
\hline 3 & Bayu Arby & 4 & 5 & 4 & 4 & 3 \\
\hline 4 & Bidar Sulistyawati & 4 & 2 & 4 & 4 & 3 \\
\hline 5 & Cici Maryati & 3 & 4 & 2 & 3 & 3 \\
\hline 6 & Citra Dewi & 4 & 2 & 3 & 3 & 3 \\
\hline 7 & Danty Indriastuti & 4 & 2 & 3 & 2 & 2 \\
\hline 8 & Dolok Parlindungan & 4 & 5 & 4 & 4 & 5 \\
\hline 9 & Fajar Febriansyah & 4 & 5 & 4 & 4 & 4 \\
\hline 10 & Gloria Fharida & 4 & 5 & 3 & 4 & 4 \\
\hline 11 & Harist & 3 & 3 & 4 & 3 & 3 \\
\hline 12 & Hasanudin & 3 & 3 & 4 & 4 & 4 \\
\hline 13 & Ika Merina & 4 & 4 & 4 & 4 & 3 \\
\hline 14 & Iqra Ali & 4 & 4 & 4 & 4 & 3 \\
\hline
\end{tabular}

\begin{tabular}{|c|c|c|c|c|c|c|}
\hline No & Nama & Absensi & TK & KK & PTK & GI \\
\hline 15 & Joddy Putranto & 4 & 4 & 3 & 4 & 3 \\
\hline 16 & Joko Sayful & 4 & 4 & 4 & 4 & 4 \\
\hline 17 & Layla Julia & 4 & 2 & 3 & 4 & 4 \\
\hline 18 & Liana Dessy & 4 & 4 & 3 & 4 & 3 \\
\hline 19 & M. Abid Mutaki & 3 & 3 & 4 & 4 & 4 \\
\hline 20 & Nyekarini & 4 & 5 & 4 & 4 & 4 \\
\hline 21 & Piyan Pirdaus & 3 & 3 & 3 & 4 & 4 \\
\hline 22 & Rizal Khoirul & 4 & 4 & 3 & 3 & 3 \\
\hline 23 & Sandi Kumiadi & 4 & 5 & 3 & 4 & 3 \\
\hline 24 & \begin{tabular}{|l|} 
Sumiyanto \\
\end{tabular} & 4 & 5 & 3 & 4 & 4 \\
\hline 25 & Waidah Nur Intan & 4 & 4 & 4 & 4 & 4 \\
\hline 26 & Windha Receiviana & 2 & 4 & 4 & 3 & 4 \\
\hline 27 & Yogie Kusuma & 3 & 4 & 4 & 4 & 4 \\
\hline \multirow[t]{2}{*}{28} & Zakaria Prasetyo & 4 & 2 & 3 & 3 & 3 \\
\hline & Profil Ideal & 5 & 5 & 4 & 5 & 4 \\
\hline
\end{tabular}

$\mathrm{TK}=\mathrm{Target} \mathrm{Kerja} ; \mathrm{KK}=\mathrm{K}$ onsentrasi Kerja; $\mathrm{PTK}=\mathrm{P}$ engetahuan Tentang Kerja; GI=Gagasan Ide

Tabel 8. Tabel Pemetaan Gap Prestasi Kerja

\begin{tabular}{|c|l|c|c|c|c|c|}
\hline No & \multicolumn{1}{|c|}{ Nama } & Absensi & TK & KK & PTK & GI \\
\hline 1 & Ade Apriliani & -1 & -1 & 0 & -1 & 0 \\
\hline 2 & Any Kustyanti & -1 & -2 & 0 & -1 & 0 \\
\hline 3 & Bayu Arby & -1 & 0 & 0 & -1 & -1 \\
\hline 4 & Bidar Sulistyawati & -1 & -3 & 0 & -1 & -1 \\
\hline 5 & Cici Maryati & -2 & -1 & -2 & -2 & -1 \\
\hline 6 & Citra Dewi & -1 & -3 & -1 & -2 & -1 \\
\hline 7 & Danty Indriastuti & -1 & -3 & -1 & -3 & -2 \\
\hline 8 & Dolok Parlindungan & -1 & 0 & 0 & -1 & 1 \\
\hline 9 & Fajar Febriansyah & -1 & 0 & 0 & -1 & 0 \\
\hline 10 & Gloria Fharida & -1 & 0 & -1 & -1 & 0 \\
\hline 11 & Harist & -2 & -2 & 0 & -2 & -1 \\
\hline 12 & Hasanudin & -2 & -2 & 0 & -1 & 0 \\
\hline 13 & Ika Merina & -1 & -1 & 0 & -1 & -1 \\
\hline 14 & Iqra Ali & -1 & -1 & 0 & -1 & -1 \\
\hline
\end{tabular}

\begin{tabular}{|c|l|c|c|c|c|c|}
\hline No & \multicolumn{1}{|c|}{ Nam a } & Absensi & TK & KK & PTK & GI \\
\hline 15 & Joddy Putranto & -1 & -1 & -1 & -1 & -1 \\
\hline 16 & Joko Sayful & -1 & -1 & 0 & -1 & 0 \\
\hline 17 & Layla Julia & -1 & -3 & -1 & -1 & 0 \\
\hline 18 & Liana Dessy & -1 & -1 & -1 & -1 & -1 \\
\hline 19 & M. Abid Mutaki & -2 & -2 & 0 & -1 & 0 \\
\hline 20 & Nyekarini & -1 & 0 & 0 & -1 & 0 \\
\hline 21 & Piyan Pirdaus & -2 & -2 & -1 & -1 & 0 \\
\hline 22 & Rizal Khoirul & -1 & -1 & -1 & -2 & -1 \\
\hline 23 & Sandi Kurniadi & -1 & 0 & -1 & -1 & -1 \\
\hline 24 & Sumiyanto & -1 & 0 & -1 & -1 & 0 \\
\hline 25 & Waidah Nur Intan & -1 & -1 & 0 & -1 & 0 \\
\hline 26 & Windha Receiviana & -3 & -1 & 0 & -2 & 0 \\
\hline 27 & Yogie Kusuma & -2 & -1 & 0 & -1 & 0 \\
\hline 28 & Zakaria Prasetyo & -1 & -3 & -1 & -2 & -1 \\
\hline
\end{tabular}

$\mathrm{TK}=$ Target $\mathrm{Kerja} ; \mathrm{KK}=\mathrm{K}$ onsentrasi Kerja; $\mathrm{PTK}=\mathrm{P}$ en getahuan $\mathrm{T}$ entang Kerja; GI=Gagasan Ide

3) Kriteria Sikap Kerja

Pada Kriteria ini dilakukan proses perhitungan gap antara profil karyawan dan profil jabatan. Profil Ideal diperoleh dari tabel penentuan bobot nilai dimana kepemimpinan bernilai 3, motivasi bernilai 5, Sistematik Kerja bernilai 5, kerjasama bernilai 3, teliti dan tanggung jawab bernilai 4 . Untuk data pemetaan gap diperoleh dari masingmasing nilai profil karyawan dikurangi profil ideal

(C2019 Teknois : Jurnal Ilmiah Teknologi Informasi dan Sains. Copyrights All rights reserved 
Volume 9 Number 2 November 2019 Page. 65-78

Journal Homepage : http://teknois.stikombinaniaga.ac.id/index.php/JBS

DOI Link : http://doi.org/10.36350/jbs.v9i2

Tabel 9. Tabel Data Sikap Kerja

\begin{tabular}{|c|l|c|c|c|c|c|}
\hline No & \multicolumn{1}{|c|}{ Nama } & KM & MV & SK & KS & TJ \\
\hline 1 & Ade Apriliani & 3 & 4 & 3 & 4 & 4 \\
\hline 2 & Any Kustyanti & 4 & 4 & 4 & 4 & 4 \\
\hline 3 & Bayu Arby & 4 & 4 & 4 & 4 & 4 \\
\hline 4 & Bidar Sulistyawati & 4 & 3 & 4 & 4 & 4 \\
\hline 5 & Cic Maryati & 4 & 3 & 3 & 3 & 3 \\
\hline 6 & Citra Dewi & 4 & 3 & 4 & 4 & 4 \\
\hline 7 & Danty Indriastuti & 3 & 2 & 3 & 4 & 3 \\
\hline 8 & Dolok Parlindungan & 5 & 4 & 4 & 4 & 4 \\
\hline 9 & Fajar Febriansyah & 4 & 4 & 4 & 4 & 4 \\
\hline 10 & Gloria Fharida & 4 & 4 & 5 & 4 & 3 \\
\hline 11 & Harist & 4 & 4 & 4 & 3 & 3 \\
\hline 12 & Hasanudin & 4 & 4 & 4 & 4 & 4 \\
\hline 13 & Ika Merina & 3 & 4 & 3 & 4 & 4 \\
\hline 14 & Iqra Ali & 3 & 4 & 3 & 4 & 4 \\
\hline
\end{tabular}

\begin{tabular}{|c|l|c|c|c|c|c|}
\hline No & \multicolumn{1}{|c|}{ Nam a } & KM & MV & SK & KS & TJ \\
\hline 15 & Joddy Putranto & 3 & 3 & 4 & 4 & 4 \\
\hline 16 & Joko Sayful & 4 & 4 & 3 & 4 & 4 \\
\hline 17 & Layla Julia & 3 & 4 & 4 & 4 & 4 \\
\hline 18 & Liana Dessy & 2 & 4 & 4 & 4 & 3 \\
\hline 19 & M Abid Mutaki & 3 & 4 & 4 & 4 & 4 \\
\hline 20 & Nyekarini & 4 & 3 & 4 & 3 & 4 \\
\hline 21 & Piyan Pirdaus & 2 & 2 & 3 & 3 & 3 \\
\hline 22 & Rizal Khoirul & 3 & 3 & 4 & 4 & 3 \\
\hline 23 & Sandi Kurniadi & 2 & 3 & 4 & 3 & 1 \\
\hline 24 & Sumiyanto & 3 & 4 & 3 & 3 & 2 \\
\hline 25 & Waidah Nur Intan & 2 & 3 & 4 & 3 & 4 \\
\hline 26 & Windha Receiviana & 4 & 3 & 3 & 4 & 4 \\
\hline 27 & Yogie Kusuma & 4 & 4 & 4 & 3 & 3 \\
\hline 28 & Zakaria Prasetyo & 3 & 2 & 4 & 3 & 3 \\
\hline \multicolumn{2}{|l|}{ Profil Ideal } & 3 & 5 & 5 & 3 & 4 \\
\hline
\end{tabular}

$\mathrm{KM}=$ Kepemimpinan; $\mathrm{MV}=$ Motivasi; $\mathrm{SK}=$ Sistematik Kerja; $\mathrm{KS}=$ Kerjasama; $\mathrm{TJ}=\mathrm{T}$ eliti dan Tanggung Jawab

Tabel 10. Tabel Pemetaan Gap Sikap Kerja

\begin{tabular}{|c|c|c|c|c|c|c|c|c|c|c|c|c|c|}
\hline No & Nama & $\mathrm{KM}$ & MV & SK & KS & TJ & No & Nama & $\mathrm{KM}$ & MV & SK & KS & $\mathrm{TJ}$ \\
\hline 1 & Ade Apriliani & 0 & \begin{tabular}{|l|l|}
-1 & \\
\end{tabular} & -2 & -1 & 0 & 15 & Joddy Putranto & 0 & -2 & -1 & 1 & 0 \\
\hline 2 & Any Kustyanti & 1 & \begin{tabular}{|l|l}
-1 \\
\end{tabular} & -1 & 1 & 0 & 16 & Joko Sayful & 1 & -1 & -2 & 1 & 0 \\
\hline 3 & Bayu Arby & 1 & \begin{tabular}{|l|l|}
-1 & - \\
\end{tabular} & -1 & 1 & 0 & 17 & Layla Julia & 0 & -1 & -1 & 1 & 0 \\
\hline 4 & Bidar Sulistyawati & 1 & \begin{tabular}{|l|l|}
-2 \\
\end{tabular} & -1 & 1 & 0 & 18 & Liana Dessy & -1 & \begin{tabular}{|l|l|}
-1 \\
\end{tabular} & -1 & 1 & -1 \\
\hline 5 & Cici Maryati & 1 & \begin{tabular}{|l|l|}
-2 \\
\end{tabular} & -2 & 0 & -1 & 19 & M Abid Mutaki & 0 & \begin{tabular}{|l|l|}
-1 \\
\end{tabular} & -1 & 1 & 0 \\
\hline 6 & Citra Dewi & 1 & \begin{tabular}{|l|}
-2 \\
\end{tabular} & -1 & 1 & 0 & 20 & Nyekarini & 1 & \begin{tabular}{l|l}
-2 & \\
\end{tabular} & -1 & 0 & 0 \\
\hline 7 & Danty In driastuti & 0 & \begin{tabular}{|l|}
-3 \\
\end{tabular} & -2 & 1 & \begin{tabular}{|l|}
-1 \\
\end{tabular} & 21 & Piyan Pirdaus & -1 & \begin{tabular}{l|l}
-3 \\
\end{tabular} & -2 & 0 & -1 \\
\hline 8 & Dolok Parlindungan & 2 & \begin{tabular}{|l|l}
-1 \\
\end{tabular} & -1 & 1 & 0 & 22 & Rizal Khoirul & 0 & -2 & -1 & 1 & 0 \\
\hline 9 & Fajar Febriansyah & 1 & \begin{tabular}{|l|l|}
-1 \\
\end{tabular} & -1 & 1 & 0 & 23 & Sandi Kurniadi & -1 & -2 & -1 & 0 & -3 \\
\hline 10 & G1oria Fharida & 1 & \begin{tabular}{|l|l}
-1 & - \\
\end{tabular} & 0 & 1 & -1 & 24 & Sumiyanto & 0 & -1 & -2 & 0 & -2 \\
\hline 11 & Harist & 1 & -1 & -1 & 0 & -1 & 25 & Waidah Nur Intan & -1 & -2 & -1 & 0 & 0 \\
\hline 12 & Hasanudin & 1 & -1 & -1 & 1 & 0 & 26 & Windha Receiviana & 1 & -2 & -2 & 1 & 0 \\
\hline 13 & Ika Merina & 0 & \begin{tabular}{|l|l}
-1 \\
\end{tabular} & -2 & 1 & 0 & 27 & Yogge Kusuma & 1 & -1 & -1 & 0 & -1 \\
\hline 14 & Iqra $\mathrm{Ali}$ & 0 & \begin{tabular}{|l|l|}
-1 & - \\
\end{tabular} & -2 & 1 & 0 & 28 & Zakaria Prasetyo & 0 & \begin{tabular}{|l|l|}
-3 \\
\end{tabular} & -1 & 0 & -1 \\
\hline
\end{tabular}

4) Kriteria Perilaku

Pada Kriteria ini dilakukan proses perhitungan gap antara profil karyawan dan profil jabatan. Profil Ideal diperoleh dari tabel penentuan bobot nilai dimana disiplin bernilai 5 , komunikasi bernilai 5 , loyalitas bernilai 3 , taat aturan bernilai 4 dan percaya diri bernilai 4 . Untuk data pemetaan gap diperoleh dari masing-masing nilai profil karyawan dikurangi profil ideal.

Tabel 11. Tabel Data Perilaku
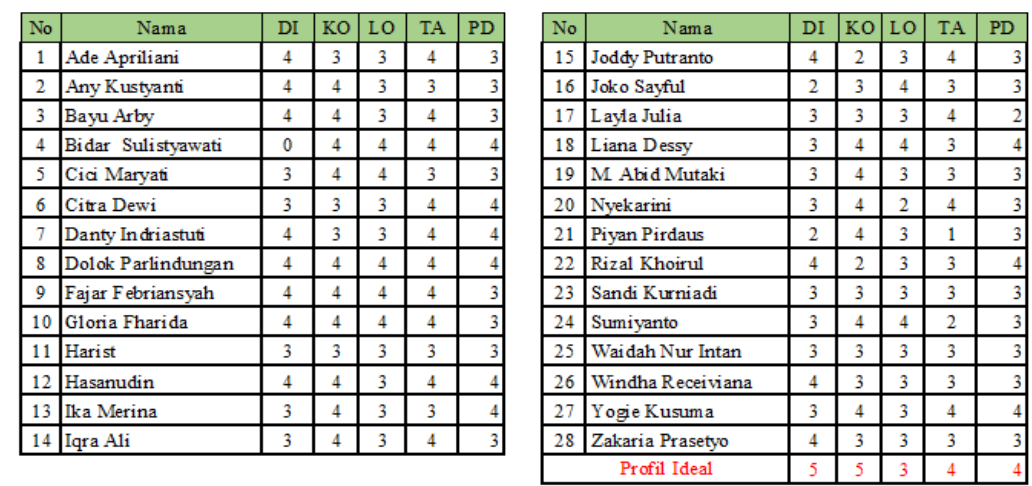

DI=Disiplin; KO=Komunikasi; LO=Loyalitas; TA $=$ Taat Aturan; PD=Percaya Diri 
Volume 9 Number 2 November 2019 Page. 65-78

Journal Homepage : http://teknois.stikombinaniaga.ac.id/index.php/JBS

DOI Link : http://doi.org/10.36350/jbs.v9i2

Tabel 12. Tabel Pemetaan Gap Perilaku

\begin{tabular}{|c|l|c|c|c|c|c|}
\hline No & \multicolumn{1}{|c|}{ Nama } & DI & KO & LO & TA & PD \\
\hline 1 & Ade Apriliani & -1 & 0 & -1 & 0 & 0 \\
\hline 2 & Any Kustyanti & -1 & 1 & -1 & -1 & 0 \\
\hline 3 & Bayu Arby & -1 & 1 & -1 & 0 & 0 \\
\hline 4 & Bidar Sulistyawati & -1 & 1 & 0 & 0 & 1 \\
\hline 5 & Cici Maryati & -2 & 1 & 0 & -1 & 0 \\
\hline 6 & Citra Dewi & -2 & 0 & -1 & 0 & 1 \\
\hline 7 & Danty Indriastuti & -1 & 0 & -1 & 0 & 1 \\
\hline 8 & Dolok Parlindungan & -1 & 1 & 0 & 0 & 1 \\
\hline 9 & Fajar Febriansyah & -1 & 1 & 0 & 0 & 0 \\
\hline 10 & Gloria Fharida & -1 & 1 & 0 & 0 & 0 \\
\hline 11 & Harist & -2 & 0 & -1 & -1 & 0 \\
\hline 12 & Hasanudin & -1 & 1 & -1 & 0 & 1 \\
\hline 13 & Ika Merina & -2 & 1 & -1 & -1 & 1 \\
\hline 14 & Iqra Ali & -2 & 1 & -1 & 0 & 0 \\
\hline
\end{tabular}

\begin{tabular}{|c|l|c|c|c|c|c|}
\hline No & \multicolumn{1}{|c|}{ Nama } & DI & KO & LO & TA & PD \\
\hline 15 & Joddy Putranto & -1 & -1 & -1 & 0 & 0 \\
\hline 16 & Joko Sayful & -3 & 0 & 0 & -1 & 0 \\
\hline 17 & Layla Julia & -2 & 0 & -1 & 0 & -1 \\
\hline 18 & Liana Dessy & -2 & 1 & 0 & -1 & 1 \\
\hline 19 & M Abid Mutaki & -2 & 1 & -1 & -1 & 0 \\
\hline 20 & Nyekarini & -2 & 1 & -2 & 0 & 0 \\
\hline 21 & Piyan Pirdaus & -3 & 1 & -1 & -3 & 0 \\
\hline 22 & Rizal Khoirul & -1 & -1 & -1 & -1 & 1 \\
\hline 23 & Sandi Kurniadi & -2 & 0 & -1 & -1 & 0 \\
\hline 24 & Sumiyanto & -2 & 1 & 0 & -2 & 0 \\
\hline 25 & Waidah Nur Intan & -2 & 0 & -1 & -1 & 0 \\
\hline 26 & Windha Receiviana & -1 & 0 & -1 & -1 & 0 \\
\hline 27 & Yogia Kusuma & -2 & 1 & -1 & 0 & 1 \\
\hline 28 & Zakaria Prasetyo & -1 & 0 & -1 & -1 & 0 \\
\hline
\end{tabular}

$\mathrm{DI}=$ Disiplin; $\mathrm{KO}=$ Komunikasi; LO=Loyalitas; $\mathrm{TA}=\mathrm{T}$ aat Aturan; $\mathrm{PD}=$ Percaya Diri

d) Perhitungan Pembobotan Berdasarkan Proses Gap Kompetensi

Setelah diperoleh nilai gap pada masing-masing karyawan, maka setiap karyawan diberi bobot nilai sesuai dengan ketentuan bobot nilai seperti pada tabel di bawah ini.

Tabel 13. Bobot Nilai Gap

\begin{tabular}{|c|c|c|c|}
\hline No & Selisih & $\begin{array}{r}\text { Bobot } \\
\text { Nilai }\end{array}$ & Keterangan \\
\hline 1 & 0 & 5 & $\begin{array}{c}\text { Tidak ada selisih (kompetensi sesuai dengan } \\
\text { yang dibutuhkan) }\end{array}$ \\
\hline 2 & 1 & 4,5 & Kompetensi individu kelebihan 1 tingkat/leve1 \\
\hline 3 & -1 & 4 & Kompetensi individu kekurangan 1 tingkat/level \\
\hline 4 & 2 & 3,5 & Kompetensi individu kelebihan 2 tingkat/leve1 \\
\hline 5 & -2 & 3 & Kompetensi individu kekurangan 2 tingkat/level \\
\hline 6 & 3 & 2,5 & Kompetensi individu kelebihan 3 tingkat/leve1 \\
\hline 7 & -3 & 2 & Kompetensi individu kekurangan 3 tingkat/level \\
\hline 8 & 4 & 1,5 & Kompetensi individu kelebihan 4 tingkat/leve1 \\
\hline 9 & -4 & 1 & Kompetensi individu kekurangan 4 tingkat/level \\
\hline
\end{tabular}

1) Kriteria Data Pribadi

Pada Kriteria ini dilakukan proses pembobotan dari hasil perhitungan nilai gap pada masing-masing karyawan.

Tabel 14. Tabel Bobot Nilai Data Pribadi

\begin{tabular}{|c|l|c|c|}
\hline No & \multicolumn{1}{|c|}{ Nama } & Pendidikan & Lama Bekerja \\
\hline 1 & Ade Apriliani & 4,5 & 3,5 \\
\hline 2 & Any Kustyanti & 4,5 & 2,5 \\
\hline 3 & Bayu Arby & 5 & 4,5 \\
\hline 4 & Bidar Sulistyawati & 4,5 & 4 \\
\hline 5 & Cici Maryati & 4,5 & 3,5 \\
\hline 6 & Citra Dewi & 5 & 4 \\
\hline 7 & Danty Indriastuti & 4,5 & 4 \\
\hline 8 & Dolok Parlindungan & 4,5 & 4,5 \\
\hline 9 & Fajar Febriansyah & 5 & 5 \\
\hline 10 & Gloria Fharida & 4,5 & 4,5 \\
\hline 11 & Harist & 5 & 4 \\
\hline 12 & Hasanudin & 4,5 & 4,5 \\
\hline 13 & Ika Merina & 5 & 4 \\
\hline 14 & Iqra Ali & 5 & 4 \\
\hline
\end{tabular}

\begin{tabular}{|c|l|c|c|}
\hline No & \multicolumn{1}{|c|}{ Nama } & Pendidikan & Lama Bekerja \\
\hline 15 & Joddy Putranto & 4,5 & 4,5 \\
\hline 16 & Joko Sayful & 5 & 4,5 \\
\hline 17 & Layla Julia & 5 & 4 \\
\hline 18 & Liana Dessy & 4,5 & 3,5 \\
\hline 19 & M. Abid & 4,5 & 3,5 \\
\hline 20 & Nyekarini & 5 & 2,5 \\
\hline 21 & Piyan Pirdaus & 3 & 3,5 \\
\hline 22 & Rizal Khoirul & 5 & 4 \\
\hline 23 & Sandi Kumiadi & 5 & 4,5 \\
\hline 24 & Sumiyanto & 5 & 2,5 \\
\hline 25 & Waidah Nur Intan & 4,5 & 4,5 \\
\hline 26 & Windha Receiviana & 4,5 & 3,5 \\
\hline 27 & Yogie Kusuma & 5 & 2,5 \\
\hline 28 & Zakaria Prasetyo & 4,5 & 4,5 \\
\hline
\end{tabular}

2) Kriteria Prestasi Kerja

Pada Kriteria ini dilakukan proses pembobotan dari hasil perhitungan nilai gap pada masing-masing karyawan. 
Volume 9 Number 2 November 2019 Page. 65-78 Journal Homepage : http://teknois.stikombinaniaga.ac.id/index.php/JBS DOI Link : http://doi.org/10.36350/jbs.v9i2

Tabel 15. Tabel Bobot Nilai Gap Prestasi Kerja

\begin{tabular}{|c|c|c|c|c|c|c|c|c|c|c|c|c|c|}
\hline No & Nama & Absensi & TK & $\mathrm{KK}$ & PIK & $\mathrm{G}$ & No & Nama & Absensi & TK & $\mathrm{KK}$ & PTK & GI \\
\hline 1 & Ade Apriliani & 4 & 4 & 5 & 4 & 5 & 15 & Joddy Putranto & 4 & 4 & 4 & 4 & 4 \\
\hline 2 & AnyKustyanti & 4 & 3 & 5 & 4 & 5 & 16 & Jolo Sayfud & 4 & 4 & 5 & 4 & 5 \\
\hline 3 & Bayn Arby & 4 & 5 & 5 & 4 & 4 & 17 & Layla Julia & 4 & 2 & 4 & 4 & 5 \\
\hline 4 & Bidar Sulistyanati & 4 & 2 & 5 & 4 & 4 & 18 & Liana Dessy & 4 & 4 & 4 & 4 & 4 \\
\hline 5 & Cici Maryati & 3 & 4 & 3 & 3 & 4 & 19 & M. Abid Mutaki & 3 & 3 & 5 & 4 & 5 \\
\hline 6 & Citra Devi & 4 & 2 & 4 & 3 & 4 & 20 & Nyekarini & 4 & 5 & 5 & 4 & 5 \\
\hline 7 & Danty Indriastuti & 4 & 2 & 4 & $\overline{2}$ & 3 & 21 & Piyan Pir daus & 3 & 3 & 4 & 4 & 5 \\
\hline 8 & Doldk Par lindungan & 4 & 5 & 5 & 4 & 4.5 & 22 & Rizal Khoind & 4 & 4 & 4 & 3 & 4 \\
\hline 9 & Fajar Febriansyah & 4 & 5 & 5 & 4 & 5 & 23 & Sandi Kurniadi & 4 & 5 & 4 & 4 & 4 \\
\hline 10 & Gloria Fharida & 4 & 5 & 4 & 4 & 5 & 24 & Sumiyanto & 4 & 5 & 4 & 4 & 5 \\
\hline 11 & Harist & 3 & 3 & 5 & 3 & 4 & 25 & Waidah Nur Intan & 4 & \begin{tabular}{|l|l|}
4 \\
\end{tabular} & 5 & 4 & 5 \\
\hline 2 & Hasenudin & 3 & 3 & 5 & 4 & 5 & 26 & Windha Receiviana & 2 & 4 & 5 & 3 & 5 \\
\hline 13 & Ika Merina & 4 & 4 & 5 & 4 & 4 & 27 & Yogie Kusuma & 3 & 4 & 5 & 4 & 5 \\
\hline 14 & Iqqra Ali & 4 & 4 & 5 & 4 & 4 & 28 & Zakaria Prasetyo & 4 & 2 & 4 & 3 & 4 \\
\hline
\end{tabular}

3) Kriteria Sikap Kerja

Pada Kriteria ini dilakukan proses pembobotan dari hasil perhitungan nilai gap pada masing-masing karyawan.

Tabel 16. Tabel Bobot Nilai Sikap Kerja

\begin{tabular}{|c|c|c|c|c|c|c|c|c|c|c|c|}
\hline 10 & Nama & $\mathrm{MN}$ & SK & $\mathrm{KS}$ & $\mathrm{TJ}$ & No & Nama & $\mathrm{MN}$ & SK & $\mathrm{KS}$ & TJ \\
\hline 1 & Ade Apriliani & 5 & 4 & 3 & 4 & 15 & Ioddy Putranto & 5 & & 4 & 4,5 \\
\hline 2 & AnyKustyanti & 4.5 & 4 & 4 & 4,5 & 16 & IdkoSayful & 4,5 & & 3 & 4.5 \\
\hline 3 & Bayu Arby & 4.5 & 2 & 4 & 4,5 & 17 & Layla Julia & 5 & & 4 & 4.5 \\
\hline 4 & Bidar Sulistyamati & 4.5 & 3 & 4 & 4,5 & 18 & Liana Dessy & 4 & & 4 & 4.5 \\
\hline 5 & Cici Maryati & 4,5 & $\overline{3}$ & 3 & 5 & 19 & M Abid Mutali & 5 & & 4 & 4.5 \\
\hline \begin{tabular}{|c|}
6 \\
\end{tabular} & Citra Deví & 4,5 & 3 & 4 & 4,5 & 20 & Nyelarini & 4,5 & & 4 & 5 \\
\hline 7 & Danty Indrastuti & 5 & 2 & 3 & 4,5 & 21 & Piyan Pirdaus & 4 & & 3 & 5 \\
\hline 8 & Doldk Par lindungan & 3,5 & 4 & 4 & 4,5 & 22 & Rizal Khoird & 5 & & 4 & 4.5 \\
\hline 9 & Fajar Febriansyah & 4.5 & 2 & 4 & 4,5 & 23 & Sandi Kumiadi & 4 & & 4 & 5 \\
\hline$\overline{10}$ & Gloria Fharida & 4,5 & $\overline{4}$ & 5 & 4,5 & 24 & Sumiyanto & $\overline{5}$ & 4 & 3 & 5 \\
\hline 11 & Harist & 4,5 & $\overline{4}$ & 4 & 5 & 25 & Waidah Nur Intan & 4 & & 4 & 5 \\
\hline$\sqrt{2}$ & Hasanudin & 4,5 & 4 & 4 & 4,5 & 26 & Windha Receiviana & 4,5 & & 3 & 4.5 \\
\hline 13 & Ika Merina & 5 & 4 & 3 & 4,5 & 27 & Yogia Kusuma & 4,5 & & 4 & 5 \\
\hline 14 & Iqgra Ali & 5 & & 3 & 4,5 & 28 & Zaharia Prasetyo & 5 & & 4 & 5 \\
\hline
\end{tabular}

MV=Motivasi; SK=Sistema tilk Kerja; KS=Kerjasama; TJ=Teliti dan Tangpung Jawab

4) Kriteria Perilaku

Pada Kriteria ini dilakukan proses pembobotan dari hasil perhitungan nilai gap pada masing-masing karyawan.

Tabel 17. Tabel Bobot Nilai Perilaku

\begin{tabular}{|c|c|c|c|c|c|c|c|c|c|c|c|c|c|}
\hline $\mathrm{No}$ & Nama & $\mathrm{DI}$ & KO & LO & TA & DD & No & Nama & $\mathrm{DI}$ & $\mathrm{KO}$ & LO & TA & PD \\
\hline 1 & Ade Appriliani & 4 & 5 & 4 & 5 & 5 & 15 & Joddy Putranto & 4 & 4 & 4 & 5 & 5 \\
\hline 2 & AnyKustyanti & 4 & 4,5 & 4 & 4 & 5 & 16 & Joho Sayfud & 2 & 5 & 5 & 4 & 5 \\
\hline 3 & Bayu Arby & 4 & 4,5 & 4 & 5 & 5 & 17 & Layla Julia & 3 & 5 & 4 & 5 & 4 \\
\hline 4 & Bidar Sulistyamati & 4 & 45 & 5 & 5 & 4,5 & 18 & Liana Dessy & 3 & 4,5 & 5 & 4 & 4,5 \\
\hline 5 & Cici Maryati & 3 & 45 & 5 & 4 & 5 & 19 & M. Abid Mutaki & 3 & 4,5 & 4 & 4 & 5 \\
\hline 6 & Citra Dewi & 3 & 5 & 4 & 5 & 4,5 & 20 & Nyekarini & 3 & 4,5 & 3 & 5 & 5 \\
\hline 7 & Danty Indr iastuti & 4 & 5 & 4 & 5 & 4,5 & 21 & Piyan Pir daus & 2 & 4,5 & 4 & 2 & 5 \\
\hline 8 & Doldk Par lindungan & 4 & 4.5 & 5 & 5 & 4.5 & 22 & Rizal Khoind & 4 & 4 & 4 & 4 & 4,5 \\
\hline 9 & Fajar Febriangah & 4 & 4.5 & 5 & 5 & 5 & 23 & Sandi Kurniadi & 3 & 5 & 4 & 4 & 5 \\
\hline 10 & Gloria Fharida & 4 & 4.5 & 5 & 5 & 5 & 24 & Sumiyanto & 3 & 4,5 & 5 & 3 & 5 \\
\hline 11 & Harist & 3 & 5 & 4 & 4 & 5 & 25 & Waidah Nur Intan & 3 & 5 & 4 & 4 & 5 \\
\hline 2 & Hasanudin & 4 & 4,5 & 4 & 5 & 4,5 & 26 & Windha Receiviana & 4 & 5 & 4 & 4 & 5 \\
\hline 13 & Ika Mer ina & 3 & 4.5 & 4 & 4 & 4,5 & 27 & Yogie Kusuma & 3 & 4,5 & 4 & 5 & 4,5 \\
\hline 14 & Iqra Ali & 3 & 4,5 & 4 & 5 & 5 & 28 & Zakaria Prasetyo & 4 & 5 & 4 & 4 & 5 \\
\hline
\end{tabular}

e) Perhitungan Core Factor dan Secondary Factor

1) Kriteria Data Pribadi

C2019 Teknois : Jurnal IImiah Teknologi Informasi dan Sains. Copyrights All rights reserved 
Volume 9 Number 2 November 2019 Page. 65-78

Journal Homepage : http://teknois.stikombinaniaga.ac.id/index.php/JBS

DOI Link : http://doi.org/10.36350/jbs.v9i2

Tabel 18. Tabel Core Factor Dan Secondary Factor Kriteria Data Pribadi

\begin{tabular}{|c|l|c|c|c|c|}
\hline No & \multicolumn{1}{|c|}{ Nama } & AB & LK & NCF & NSF \\
\hline 1 & Ade Apriliani & 4,5 & 3,5 & 3,5 & 4,5 \\
\hline 2 & Any Kustyanti & 4,5 & 2,5 & 2,5 & 4,5 \\
\hline 3 & Bayu Arby & 5 & 4,5 & 4,5 & 5 \\
\hline 4 & Bidar Sulistyawati & 4,5 & 4 & 4 & 4,5 \\
\hline 5 & Cici Maryati & 4,5 & 3,5 & 3,5 & 4,5 \\
\hline 6 & Citra Dewi & 5 & 4 & 4 & 5 \\
\hline 7 & Danty Indriastuti & 4,5 & 4 & 4 & 4,5 \\
\hline 8 & Dolok Parlindungan & 4,5 & 4,5 & 4,5 & 4,5 \\
\hline 9 & Fajar Febriansyah & 5 & 5 & 5 & 5 \\
\hline 10 & Gloria Fharida & 4,5 & 4,5 & 4,5 & 4,5 \\
\hline 11 & Harist & 5 & 4 & 4 & 5 \\
\hline 12 & Hasanudin & 4,5 & 4,5 & 4,5 & 4,5 \\
\hline 13 & Ika Merina & 5 & 4 & 4 & 5 \\
\hline 14 & Iqra Ali & 5 & 4 & 4 & 5 \\
\hline
\end{tabular}

\begin{tabular}{|c|l|c|c|c|c|}
\hline No & \multicolumn{1}{|c|}{ Nama } & AB & LK & NCF & NSF \\
\hline 15 & Joddy Putranto & 4,5 & 4,5 & 4,5 & 4,5 \\
\hline 16 & Joko Sayful & 5 & 4,5 & 4,5 & 5 \\
\hline 17 & Layla Julia & 5 & 4 & 4 & 5 \\
\hline 18 & Liana Dessy & 4,5 & 3,5 & 3,5 & 4,5 \\
\hline 19 & M Abid Mutaki & 4,5 & 3,5 & 3,5 & 4,5 \\
\hline 20 & Nyekarini & 5 & 2,5 & 2,5 & 5 \\
\hline 21 & Piyan Pirdaus & 3 & 3,5 & 3,5 & 3 \\
\hline 22 & Rizal Khoirul & 5 & 4 & 4 & 5 \\
\hline 23 & Sandi Kurniadi & 5 & 4,5 & 4,5 & 5 \\
\hline 24 & Sumiyanto & 5 & 2,5 & 2,5 & 5 \\
\hline 25 & Waidah Nur Intan & 4,5 & 4,5 & 4,5 & 4,5 \\
\hline 26 & Windha Receiviana & 4,5 & 3,5 & 3,5 & 4,5 \\
\hline 27 & Yogie Kusuma & 5 & 2,5 & 2,5 & 5 \\
\hline 28 & Zakaria Prasetyo & 4,5 & 4,5 & 4,5 & 4,5 \\
\hline
\end{tabular}

2) Kriteria Prestasi Kerja

Tabel 19. Tabel Core Factor Dan Secondary Factor Kriteria Prestasi Kerja

\begin{tabular}{|c|c|c|c|c|c|c|c|c|}
\hline $\mathrm{N}_{0}$ & Nana & $A B$ & TK & $\mathrm{KK}$ & PIK & $\mathrm{GI}$ & $\mathrm{NCF}$ & NSP \\
\hline 1 & Ada Apriliani & 4 & 4 & 5 & 4 & 5 & 4 & 5 \\
\hline 2 & AnyKustyanti & 4 & 3 & 5 & 4 & 5 & 3,66 & $\overline{5}$ \\
\hline 3 & Bays Arby & 4 & 5 & 5 & 4 & 4 & 4,33 & 4.5 \\
\hline 4 & Bidar Sulistyanati & 4 & 2 & 5 & 4 & 4 & 3,33 & 4.5 \\
\hline 5 & Cici Maryati & 3 & 4 & 3 & 3 & 4 & 3,33 & 3,5 \\
\hline 6 & Citra Dewri & 4 & 2 & 4 & 3 & 4 & 3 & 4 \\
\hline 7 & Danty Indriastuti & 4 & 2 & 4 & 2 & 3 & 2,66 & 3,5 \\
\hline 8 & Doldk Parlindengan & 4 & 5 & 5 & 4 & 4,5 & 4,33 & 475 \\
\hline 9 & Fajar Felbriansyah & 4 & 5 & 5 & 4 & 5 & 4,33 & 5 \\
\hline 10 & Goria Fhar ida & 4 & 5 & 4 & 4 & 5 & 4,33 & 4.5 \\
\hline 11 & Harist & 3 & 3 & 5 & 3 & 4 & 3 & 4,5 \\
\hline 12 & Hasanudin & 3 & 3 & 5 & 4 & 5 & 3,33 & 5 \\
\hline 13 & Ita Nerina & 4 & 4 & 5 & 4 & 4 & 4 & 4.5 \\
\hline 14 & Iqua Ali & 4 & 4 & 5 & 4 & 4 & 4 & 4.5 \\
\hline
\end{tabular}

\begin{tabular}{|c|c|c|c|c|c|c|c|c|}
\hline 0 & Nama & $A B$ & TK & $\mathrm{KK}$ & PIK & GI & $\mathrm{NCF}$ & $\mathrm{NSF}$ \\
\hline 15 & Joddy Putranto & 4 & 4 & 4 & 4 & 4 & 4 & 4 \\
\hline 16 & Jokto Sayfud & 4 & 4 & 5 & 4 & 5 & 4 & 5 \\
\hline 17 & Layla Julia & 4 & 2 & 4 & 4 & 5 & 3,33 & 4,5 \\
\hline 18 & Liana Dxsy & 4 & 4 & 4 & 4 & 4 & 4 & 4 \\
\hline 19 & M. Abid Mutaki & 3 & 3 & 5 & 4 & 5 & 3,33 & 5 \\
\hline 20 & Nyefarini & 4 & 5 & 5 & 4 & 5 & 4,33 & 5 \\
\hline 21 & Piyan Pirctus & 3 & 3 & 4 & 4 & 5 & 3,33 & 4.5 \\
\hline 22 & Rizal Khoind & 4 & 4 & 4 & 3 & 4 & 3,66 & 4 \\
\hline 23 & Sand Kumiadi & 4 & 5 & 4 & 4 & 4 & 4,33 & 4 \\
\hline 24 & Suarianto & 4 & 5 & 4 & 4 & 5 & 4,33 & 4.5 \\
\hline 25 & Waidah Nur Inten & 4 & 4 & 5 & 4 & 5 & 4 & 5 \\
\hline 26 & Windna Reciviana & 2 & 4 & 5 & 3 & 5 & 3 & 5 \\
\hline 27 & Yogje Kusum a & 3 & 4 & 5 & 4 & 5 & 3,66 & 5 \\
\hline 28 & Zalaria Prastyo & 4 & 2 & 4 & 3 & 4 & 3 & 4 \\
\hline
\end{tabular}

3) Kriteria Sikap Kerja

Tabel 20. Tabel Core Factor Dan Secondary Factor Kriteria Sikap Kerja

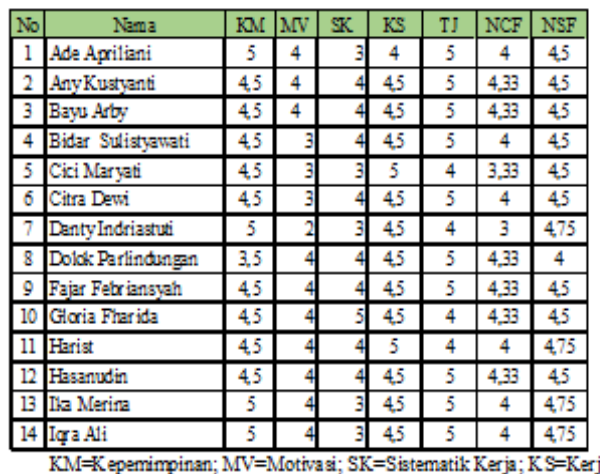

\begin{tabular}{|c|c|c|c|c|c|c|c|c|}
\hline No & Nama & $\mathrm{KM}$ & $\mathrm{MV}$ & SK & $\mathrm{KS}$ & TJ & $\mathrm{NCF}$ & $\mathrm{NSF}$ \\
\hline 15 & Joddy Putranto & 5 & 3 & 4 & 4.5 & 5 & 4 & 4,75 \\
\hline 16 & Joho Sayful & 4.5 & & 3 & 4.5 & 5 & 4 & 4.5 \\
\hline \begin{tabular}{|l|}
17 \\
\end{tabular} & Layla Julia & 5 & 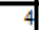 & 4 & 4.5 & 5 & 4,33 & 4,75 \\
\hline 18 & Liana Desyy & 4 & & 4 & 4.5 & 4 & 4 & 4,25 \\
\hline 19 & M. Abid Mutaki & 5 & 4 & 4 & 4,5 & 5 & 4,33 & 4,75 \\
\hline 20 & Nyelar ini & 4,5 & 司 & 4 & 5 & 5 & 4 & 4,75 \\
\hline 21 & Piyan Pirdaus & 4 & 2 & 3 & 5 & 4 & 3 & 4,5 \\
\hline 22 & Rizal Khoind & 5 & 司 & 4 & 4,5 & 5 & 4 & 4,75 \\
\hline 23 & Sandi Kumiadi & 4 & 司 & 4 & 5 & 2 & 3 & 4.5 \\
\hline 24 & Sumizanto & 5 & 4 & 可 & 5 & 3 & 3,33 & 5 \\
\hline 25 & Waidah Nux Intan & 4 & 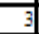 & 4 & 5 & 5 & 4 & 4,5 \\
\hline 26 & Windha Receiviana & 4,5 & 3 & 3 & 4.5 & 5 & 4,33 & 4.5 \\
\hline 27 & Yogje Kusum a & 4,5 & 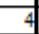 & 4 & 5 & 4 & 4 & 4,75 \\
\hline 28 & Zalaria Prasatyo & 5 & & 4 & 5 & 4 & 3,33 & 5 \\
\hline
\end{tabular}

4) Kriteria Perilaku

Tabel 21. Tabel Core Factor Dan Secondary Factor Kriteria Perilaku

\begin{tabular}{|c|c|c|c|c|c|c|c|c|c|c|c|c|c|c|c|c|c|}
\hline No & Nama & DI & KO & IO & TA & DD & $\mathrm{NCF}$ & NSF & No & Nama & DI & $\mathrm{KD}$ & LO & TA & PD & $\mathrm{NCF}$ & NSF \\
\hline 1 & Ads Apriliani & 4 & 5 & 4 & 5 & 5 & 4,5 & 4,66 & 15 & Joddy Putranto & 4 & 4 & 4 & 5 & 5 & 4,5 & 4,33 \\
\hline 2 & AnyKustyanti & 4 & 4.5 & 4 & 4 & 5 & 4 & 4.5 & 16 & Joho Sayful & 2 & 5 & 5 & 4 & 5 & 3 & 5 \\
\hline 3 & Bayu Arby & 4 & 4.5 & 4 & 5 & 5 & 4,5 & 4,5 & 17 & Layła Julia & 3 & 5 & 4 & 5 & 4 & 4 & 4,33 \\
\hline 4 & Bidar Sulistyanati & 4 & 4,5 & 5 & 5 & 4,5 & 4,5 & 4,66 & 18 & Liana Desy & 3 & 4,5 & 5 & 4 & 4,5 & 3,5 & 4,66 \\
\hline 5 & Cici Maryati & 3 & 4,5 & 5 & 4 & 5 & 3,5 & 4,83 & 19 & M. Abid Mutaki & 3 & 4,5 & 4 & 4 & 5 & 3,5 & 4,5 \\
\hline 6 & Citra Dewi & 3 & 5 & 4 & 5 & 4.5 & 4 & 4.5 & 20 & Nyelarini & 3 & 4,5 & 3 & 5 & 5 & 4 & 4,16 \\
\hline 7 & DentyIndriastuti & 4 & 5 & 4 & 5 & 4,5 & 4,5 & 4.5 & 21 & Piyan Pirdaus & 2 & 4,5 & 4 & 2 & 5 & 2 & 4,5 \\
\hline 8 & Doldk Parlindengan & 4 & 4.5 & 5 & 5 & 4,5 & 4,5 & 4,66 & 22 & Rizal Whoigd & 4 & 4 & 4 & 4 & 4,5 & 4 & 4,16 \\
\hline 9 & Fajar Febriansyah & 4 & 4.5 & 5 & 5 & 5 & 4,5 & 4,83 & 23 & Sandi Kumiadi & 3 & 5 & 4 & 4 & 5 & 3,5 & 4,66 \\
\hline 10 & Gloria Fhar ida & 4 & 4.5 & 5 & 5 & 5 & 4,5 & 4,83 & 24 & Sumianto & 3 & 4,5 & 5 & 3 & 5 & 3 & 4,83 \\
\hline 11 & Harist & 3 & 5 & 4 & 4 & 5 & 3,5 & 4,66 & 25 & Wa idah Nux Inten & 3 & 5 & 4 & 4 & 5 & 3,5 & 4,66 \\
\hline 12 & Hasanudin & 4 & 4,5 & 4 & 5 & 4,5 & 4,5 & 4,33 & 26 & Windha Receiviana & 4 & 5 & 4 & 4 & 5 & 4 & 4,66 \\
\hline 13 & Ila Merina & 3 & 4.5 & 4 & 4 & 4.5 & 3,5 & 4,33 & 27 & Yogie Kusum a & 3 & 4,5 & 4 & 5 & 4,5 & 4 & 4,33 \\
\hline 14 & Iqua Ali & 3 & 4,5 & 4 & 5 & 5 & 4 & 4,5 & 28 & Zajaria Praselyo & 4 & 5 & 4 & 4 & 5 & 4 & 4,66 \\
\hline
\end{tabular}

C2019 Teknois : Jurnal Ilmiah Teknologi Informasi dan Sains. Copyrights All rights reserved 
f) Perhitungan Nilai Total

Dari hasil perhitungan setiap aspek di atas, berikutnya dihitung nilai total berdasarkan presentase dari Core Factor dan Secondary Factor yang diperkirakan berpengaruh terhadap kinerja tiap-tiap profil. Contoh perhitungan dapat dilihat pada rumus di bawah ini:

1) Kriteria Data Pribadi

Tabel 22. Tabel Perhitungan Nilai Total Data Pribadi

\begin{tabular}{|c|l|c|c|c|}
\hline No & \multicolumn{1}{|c|}{ Nama } & NCF & NSF & NDP \\
\hline 1 & Ade Apriliani & 3,5 & 4,5 & 3,9 \\
\hline 2 & Any Kustyanti & 2,5 & 4,5 & 3,3 \\
\hline 3 & Bayu Arby & 4,5 & 5 & 4,7 \\
\hline 4 & Bidar Sulistyaw ati & 4 & 4,5 & 4,2 \\
\hline 5 & Cici Maryati & 3,5 & 4,5 & 3,9 \\
\hline 6 & Citra Dewi & 4 & 5 & 4,4 \\
\hline 7 & Danty Indriastuti & 4 & 4,5 & 4,2 \\
\hline 8 & Dolok Parlindungan & 4,5 & 4,5 & 4,5 \\
\hline 9 & Fajar Febriansyah & 5 & 5 & 5 \\
\hline 10 & Gloria Fharida & 4,5 & 4,5 & 4,5 \\
\hline 11 & Harist & 4 & 5 & 4,4 \\
\hline 12 & Hasanudin & 4,5 & 4,5 & 4,5 \\
\hline 13 & Ika Merina & 4 & 5 & 4,4 \\
\hline 14 & Iqra Ali & 4 & 5 & 4,4 \\
\hline
\end{tabular}

\begin{tabular}{|c|l|c|c|c|}
\hline No & \multicolumn{1}{|c|}{ Nama } & NCF & NSF & NDP \\
\hline 15 & Joddy Putranto & 4,5 & 4,5 & 4,5 \\
\hline 16 & Joko Sayful & 4,5 & 5 & 4,7 \\
\hline 17 & Layla Julia & 4 & 5 & 4,4 \\
\hline 18 & Liana Dessy & 3,5 & 4,5 & 3,9 \\
\hline 19 & M. Abid Mutaki & 3,5 & 4,5 & 3,9 \\
\hline 20 & Nyekarini & 2,5 & 5 & 3,5 \\
\hline 21 & Piyan Pirdaus & 3,5 & 3 & 3,5 \\
\hline 22 & Rizal Khoirul & 4 & 5 & 4,4 \\
\hline 23 & Sandi Kurniadi & 4,5 & 5 & 4,7 \\
\hline 24 & Sumiyanto & 2,5 & 5 & 3,5 \\
\hline 25 & Waidah Nur Intan & 4,5 & 4,5 & 4,5 \\
\hline 26 & Windha Receiviana & 3,5 & 4,5 & 3,9 \\
\hline 27 & Yogie Kusum a & 2,5 & 5 & 3,5 \\
\hline 28 & Zakaria Prasetyo & 4,5 & 4,5 & 4,5 \\
\hline
\end{tabular}

2) Kriteria Prestasi Kerja

Tabel 23. Tabel Perhitungan Nilai Total Prestasi Kerja

\begin{tabular}{|c|l|c|c|c|}
\hline No & \multicolumn{1}{|c|}{ Nama } & NCF & NSF & NDP \\
\hline 1 & Ade Apriliani & 4 & 5 & 4,4 \\
\hline 2 & Any Kustyanti & 3,66 & 5 & 4,196 \\
\hline 3 & Bayu Arby & 4,33 & 4,5 & 4,398 \\
\hline 4 & Bidar Sulistyawati & 3,33 & 4,5 & 3,798 \\
\hline 5 & Cici Maryati & 3,33 & 3,5 & 3,898 \\
\hline 6 & Citra Dewi & 3 & 4 & 3,4 \\
\hline 7 & Danty Indriastuti & 2,66 & 3,5 & 2,996 \\
\hline 8 & Dolok Parlindungan & 4,33 & 4,75 & 4,498 \\
\hline 9 & Fajar Febriansyah & 4,33 & 5 & 4,598 \\
\hline 10 & Gloria Fharida & 4,33 & 4,5 & 4,398 \\
\hline 11 & Harist & 3 & 4,5 & 3,6 \\
\hline 12 & Hasanudin & 3,33 & 5 & 3,998 \\
\hline 13 & Ika Merina & 4 & 4,5 & 4,2 \\
\hline 14 & Iqra Ali & 4 & 4,5 & 4,2 \\
\hline
\end{tabular}

\begin{tabular}{|c|l|c|c|c|}
\hline No & \multicolumn{1}{|c|}{ Nam a } & NCF & NSF & NDP \\
\hline 15 & Joddy Putranto & 4 & 4 & 4 \\
\hline 16 & Joko Sayful & 4 & 5 & 4,4 \\
\hline 17 & Layla Julia & 3,33 & 4,5 & 3,798 \\
\hline 18 & Liana Dessy & 4 & 4 & 4 \\
\hline 19 & M. Abid Mutaki & 3,33 & 5 & 3,998 \\
\hline 20 & Nyekarini & 4,33 & 5 & 4,598 \\
\hline 21 & Piyan Pirdaus & 3,33 & 4,5 & 3,798 \\
\hline 22 & Rizal Khoirul & 3,66 & 4 & 3,796 \\
\hline 23 & Sandi Kurniadi & 4,33 & 4 & 4,198 \\
\hline 24 & Sumiyanto & 4,33 & 4,5 & 4,398 \\
\hline 25 & Waidah Nur Intan & 4 & 5 & 4,4 \\
\hline 26 & Windha Receiviana & 3 & 5 & 3,8 \\
\hline 27 & Yogie Kusuma & 3,66 & 5 & 4,196 \\
\hline 28 & Zakaria Prasetyo & 3 & 4 & 3,4 \\
\hline
\end{tabular}

3) Kriteria Sikap Kerja

Tabel 24. Tabel Perhitungan Nilai Total Kriteria Sikap Kerja

\begin{tabular}{|c|l|c|r|c|}
\hline No & \multicolumn{1}{|c|}{ Nama } & NCF & NSF & NDP \\
\hline 1 & Ade Apriliani & 4 & 4,5 & 4,2 \\
\hline 2 & Any Kustyanti & 4,33 & 4,5 & 4,398 \\
\hline 3 & Bayu Arby & 4,33 & 4,5 & 4,398 \\
\hline 4 & Bidar Sulistyawati & 4 & 4,5 & 3,2 \\
\hline 5 & Cici Maryati & 3,33 & 4,5 & 3,898 \\
\hline 6 & Citra Dewi & 4 & 4,5 & 4,2 \\
\hline 7 & Danty Indriastuti & 3 & 4,75 & 3,7 \\
\hline 8 & Dolok Parlindungan & 4,33 & 4 & 4,198 \\
\hline 9 & Fajar Febriansyah & 4,33 & 4,5 & 4,398 \\
\hline 10 & Gloria Fharida & 4,33 & 4,5 & 4,398 \\
\hline 11 & Harist & 4 & 4,75 & 4,3 \\
\hline 12 & Hasanudin & 4,33 & 4,5 & 4,398 \\
\hline 13 & Ika Merina & 4 & 4,75 & 4,3 \\
\hline 14 & Iqra Ali & 4 & 4,75 & 4,3 \\
\hline
\end{tabular}

\begin{tabular}{|r|l|c|r|c|}
\hline No & \multicolumn{1}{|c|}{ Nama } & NCF & NSF & NDP \\
\hline 15 & Joddy Putranto & \multicolumn{1}{c|}{4} & 4,75 & 4,3 \\
\hline 16 & Joko Sayful & 4 & 4,5 & 4,2 \\
\hline 17 & Layla Julia & 4,33 & 4,75 & 4,498 \\
\hline 18 & Liana Dessy & 4 & 4,25 & 4,1 \\
\hline 19 & M. Abid Mutaki & 4,33 & 4,75 & 4,498 \\
\hline 20 & Nyekarini & 4 & 4,75 & 4,3 \\
\hline 21 & Piyan Pirdaus & 3 & 4,5 & 3,6 \\
\hline 22 & Rizal Khoirul & 4 & 4,75 & 4,3 \\
\hline 23 & Sandi Kurniadi & 3 & 4,5 & 3,6 \\
\hline 24 & Sumiyanto & 3,33 & 5 & 3,998 \\
\hline 25 & Waidah Nur Intan & 4 & 4,5 & 4,2 \\
\hline 26 & Windha Receiviana & 4,33 & 4,5 & 4,398 \\
\hline 27 & Yogie Kusuma & 4 & 4,75 & 4,3 \\
\hline 28 & Zakaria Prasetyo & 3,33 & 5 & 3,998 \\
\hline
\end{tabular}


Volume 9 Number 2 November 2019 Page. 65-78

Journal Homepage : http://teknois.stikombinaniaga.ac.id/index.php/JBS

DOI Link : http://doi.org/10.36350/jbs.v9i2

4) Kriteria Perilaku

Tabel 25. Perhitungan Nilai Total Kriteria Perilaku

\begin{tabular}{|c|l|c|r|c|}
\hline No & \multicolumn{1}{|c|}{ Nama } & NCF & NSF & NDP \\
\hline 1 & Ade Apriliani & 4,5 & 4,66 & 4,564 \\
\hline 2 & Any Kustyanti & 4 & 4,5 & 4,2 \\
\hline 3 & Bayu Arby & 4,5 & 4,5 & 4,5 \\
\hline 4 & Bidar Sulistyawati & 4,5 & 4,66 & 4,564 \\
\hline 5 & Cici Maryati & 3,5 & 4,83 & 4,032 \\
\hline 6 & Citra Dewi & 4 & 4,5 & 4,2 \\
\hline 7 & Danty Indriastuti & 4,5 & 4,5 & 4,5 \\
\hline 8 & Dolok Parlindungan & 4,5 & 4,66 & 4,564 \\
\hline 9 & Fajar Febriansyah & 4,5 & 4,83 & 4,632 \\
\hline 10 & Gloria Fharida & 4,5 & 4,83 & 4,632 \\
\hline 11 & Harist & 3,5 & 4,66 & 3,964 \\
\hline 12 & Hasanudin & 4,5 & 4,33 & 4,432 \\
\hline 13 & Ika Merina & 3,5 & 4,33 & 3,832 \\
\hline 14 & Iqra Ali & 4 & 4,5 & 4,2 \\
\hline
\end{tabular}

\begin{tabular}{|r|l|c|c|c|}
\hline No & \multicolumn{1}{|c|}{ Nama } & NCF & NSF & \multicolumn{1}{c|}{ NDP } \\
\hline 15 & Joddy Putranto & 4,5 & 4,33 & 4,432 \\
\hline 16 & Joko Sayful & 3 & \multicolumn{1}{c|}{5} & 3,8 \\
\hline 17 & Layla Julia & 4 & 4,33 & 4,132 \\
\hline 18 & Liana Dessy & 3,5 & 4,66 & 3,964 \\
\hline 19 & M. Abid Mutaki & 3,5 & 4,5 & 3,9 \\
\hline 20 & Nyekarini & 4 & 4,16 & 4,064 \\
\hline 21 & Piyan Pirdaus & 2 & 4,5 & 3 \\
\hline 22 & Rizal Khoirul & 4 & 4,16 & 4,064 \\
\hline 23 & Sandi Kurniadi & 3,5 & 4,66 & 3,964 \\
\hline 24 & Sumiyanto & 3 & 4,83 & 3,732 \\
\hline 25 & Waidah Nur Intan & 3,5 & 4,66 & 3,964 \\
\hline 26 & Windha Receiviana & 4 & 4,66 & 4,264 \\
\hline 27 & Yogie Kusuma & 4 & 4,33 & 4,132 \\
\hline 28 & Zakaria Prasetyo & 4 & 4,66 & 4,264 \\
\hline
\end{tabular}

g) Perhitungan Penentuan Ranking

Hasil akhir dari proses Profile Matching adalah ranking dari karyawan yang akan diangkat untuk naik level. Perhitungan ranking bisa ditunjukkan dengan rumus sebagai berikut: Ranking $=(30 \% \cdot$ NilaiDP $)+(30 \% \cdot$ NilaiPK $)+(20 \% \cdot$ NilaiSK $)+(20 \% \cdot$ NilaiPerilaku $)$

Tabel 26. Tabel Perhitungan Penentuan Ranking

\begin{tabular}{|c|l|c|c|c|c|c|}
\hline No & \multicolumn{1}{|c|}{ Nama } & NDP & NPK & NSK & NP & Ranking \\
\hline 1 & Ade Apriliani & 3,9 & 4,4 & 4,2 & 4,564 & 4,243 \\
\hline 2 & Any Kustyanti & 3,3 & 4,196 & 4,398 & 4,2 & 3,968 \\
\hline 3 & Bayu Arby & 4,7 & 4,398 & 4,398 & 4,5 & 4,509 \\
\hline 4 & Bidar Sulistyawati & 4,2 & 3,798 & 3,2 & 4,564 & 3,952 \\
\hline 5 & Cici Maryati & 3,9 & 3,898 & 3,898 & 4,032 & 3,925 \\
\hline 6 & Citra Dewi & 4,4 & 3,4 & 4,2 & 4,2 & 4,020 \\
\hline 7 & Danty Indriastuti & 4,2 & 2,996 & 3,7 & 4,5 & 3,799 \\
\hline 8 & Dolok Parlindungan & 4,5 & 4,498 & 4,198 & 4,564 & 4,452 \\
\hline 9 & Fajar Febriansyah & 5 & 4,598 & 4,398 & 4,632 & 4,685 \\
\hline 10 & Gloria Fharida & 4,5 & 4,398 & 4,398 & 4,632 & 4,475 \\
\hline 11 & Harist & 4,4 & 3,6 & 4,3 & 3,964 & 4,053 \\
\hline 12 & Hasanudin & 4,5 & 3,998 & 4,398 & 4,432 & 4,315 \\
\hline 13 & Ika Merina & 4,4 & 4,2 & 4,3 & 3,832 & 4,206 \\
\hline 14 & Iqra Ali & 4,4 & 4,2 & 4,3 & 4,2 & 4,280 \\
\hline
\end{tabular}

\begin{tabular}{|c|l|c|c|c|c|c|}
\hline No & \multicolumn{1}{|c|}{ Nama } & NDP & NPK & NSK & NP & Ranking \\
\hline 15 & Joddy Putranto & 4,5 & 4 & 4,3 & 4,432 & 4,296 \\
\hline 16 & Joko Sayful & 4,7 & 4,4 & 4,2 & 3,8 & 4,330 \\
\hline 17 & Layla Julia & 4,4 & 3,798 & 4,498 & 4,132 & 4,185 \\
\hline 18 & Liana Dessy & 3,9 & 4 & 4,1 & 3,964 & 3,983 \\
\hline 19 & M. Abid Mutaki & 3,9 & 3,998 & 4,498 & 3,9 & 4,049 \\
\hline 20 & Nyekarini & 3,5 & 4,598 & 4,3 & 4,064 & 4,102 \\
\hline 21 & Piyan Pirdaus & 3,5 & 3,798 & 3,6 & 3 & 3,509 \\
\hline 22 & Rizal Khoirul & 4,4 & 3,796 & 4,3 & 4,064 & 4,132 \\
\hline 23 & Sandi Kurniadi & 4,7 & 4,198 & 3,6 & 3,964 & 4,182 \\
\hline 24 & Sumiyanto & 3,5 & 4,398 & 3,998 & 3,732 & 3,915 \\
\hline 25 & Waidah Nur Intan & 4,5 & 4,4 & 4,2 & 3,964 & 4,303 \\
\hline 26 & Windha Receiviana & 3,9 & 3,8 & 4,398 & 4,264 & 4,042 \\
\hline 27 & Yogie Kusuma & 4,5 & 4,196 & 4,3 & 4,132 & 4,295 \\
\hline 28 & Zakaria Prasetyo & 4,5 & 3,4 & 3,998 & 4,264 & 4,022 \\
\hline
\end{tabular}

Hasil akhir dari perhitungan kinerja analisa di atas dengan menggunakan metode Profile Matching (Pencocokan Profil) adalah sebagai berikut:

Tabel 27. Tabel Hasil Kinerja

\begin{tabular}{|c|l|c|}
\hline No & \multicolumn{1}{|c|}{ Nama } & Ranking \\
\hline 1 & Fajar Febriansyah & 4,685 \\
\hline 2 & Bayu Arby & 4,509 \\
\hline 3 & Gloria Fharida & 4,475 \\
\hline 4 & Dolok Parlindungan & 4,452 \\
\hline 5 & Joko Sayful & 4,330 \\
\hline 6 & Hasanudin & 4,315 \\
\hline 7 & Waidah Nur Intan & 4,303 \\
\hline 8 & Joddy Putranto & 4,296 \\
\hline 9 & Yogie Kusuma & 4,295 \\
\hline 10 & Iqra Ali & 4,280 \\
\hline 11 & Ade Apriliani & 4,243 \\
\hline 12 & Ika Merina & 4,206 \\
\hline 13 & Layla Julia & 4,185 \\
\hline 14 & Sandi Kurniadi & 4,182 \\
\hline
\end{tabular}

\begin{tabular}{|c|l|c|}
\hline No & \multicolumn{1}{|c|}{ Nama } & Ranking \\
\hline 15 & Rizal Khoirul & 4,132 \\
\hline 16 & Nyekarini & 4,102 \\
\hline 17 & Harist & 4,053 \\
\hline 18 & M. Abid Mutaki & 4,049 \\
\hline 19 & Windha Receiviana & 4,042 \\
\hline 20 & Zakaria Prasetyo & 4,022 \\
\hline 21 & Citra Dewi & 4,020 \\
\hline 22 & Liana Dessy & 3,983 \\
\hline 23 & Any Kustyanti & 3,968 \\
\hline 24 & Bidar Sulistyawati & 3,952 \\
\hline 25 & Cici Maryati & 3,925 \\
\hline 26 & Sumiyanto & 3,915 \\
\hline 27 & Danty Indriastuti & 3,799 \\
\hline 28 & Piyan Pirdaus & 3,509 \\
\hline
\end{tabular}




\section{KESIMPULAN}

Berdasarkan penelitian yang dilakukan pada PT. Infomedia Solusi Humanika untuk menentukan kenaikan level pada karyawan, maka dapat disimpulkan:

1. Profile Matching (Pencocokan Profil) dapat menentukan nilai beberapa kriteria yang kompleks, contoh dalam penelitian ini diantaranya kriteria Data Pribadi, kriteria Prestasi Kerja, kriteria Sikap Kerja dan kriteria Perilaku.

2. Metode Profile Matching terbukti dapat membantu para Manajer / Pengambil Keputusan dalam menentukan karyawan yang layak/kompeten untuk naik level, yang mana kenaikan level tersebut dapat mempengaruhi kenaikan gaji.

3. Berdasarkan hasil perhitungan menggunakan regresi linier dan uji hipotesis bahwa kriteria Prestasi Kerja sangat signifikan atau sangat berpengaruh terhadap penilaian kinerja karyawan

\section{E. DAFTAR PUSTAKA}

[1] Arikunto, Suharsimi. 2015. Manajemen Penelitian. Edisi Revisi. Rineka Cipta. Jakarta.

[2] Faizal, E. 2014. Metode Profile Matching Untuk Penentuan Penerimaan Usulan Penelitian internal Dosen STMIK El Rahma. Journal Speed - Sentra Penelitian Engineering dan Edukasi - Volume 6 No 1 - 2014.

[3] Farida, I, N. 2016. Implementasi Metode Profile Matching Untuk Evaluasi Potensi Akademik Penjurusan Siswa MAN 2 Kota Kediri. Jurnal Infotel Vol.8 No.2 November 2016

[4] Kasmir. 2018. Manajemen Sumber Daya Manusia. Edisi Cetakan ke IV. Depok

[5] Kusrini, 2007. Konsep dan Aplikasi Sistem Pendukung Keputusan. Yogyakarta

[6] Purwanto, H. 2017. Penerapan Metode Profile Matching Dalam Sistem Pendukung Keputusan Penilaian Kinerja Karyawan Pada PT.Hyundai Mobil Indonesia Cabang Kalimalang Jurnal Techno Nusa Mandiri Vol. XIV, No. 1 Maret 2017

[7] Rachmawati, Kusdiyah, I. 2008. Manajemen Sumber Daya Manusia. Edisi Pertama, Cetakan Pertama. Andi Offset, Jakarta.

[8] Sambani, E, B. Mulyana, D and Maulana, I. 2016. Sistem Pendukung Keputusan Kelayakan Penerimaan Pengajar Menggunakan Metode Profile Matching. Journal of Applied Intelligent System, Vol. 1, No. 2, Juni 2016: 103 - 112.

[9] Sudarmadi, A. Santoso and E. Sutrisno.2017. Sistem Pendukung Keputusan Peilihan Personel Homeband Universitas Brawijaya Menggunakan Metode Profile Matching. Jurnal Pengembangan Teknologi Informasi dan Ilmu Komputer e-ISSN: 2548-964X Vol.1, No. 12, Desember 2017, hlm. 1788-1796).

[10] Sugiyono. 2014. Metode Penelitian Kuantitatif, Kualitatif Dan R\&D. Alfabeta. Bandung.

[11] Sumarsan and Thomas, 2013. Sistem Pengendalian Manajemen. Indeks, Jakarta.

[12] Sunyoto, Danang, 2009. Ananlisis Regresi dan Uji Hipotesis. Cetakan I, Yogyakarta.

[13] Suyono, 2018. Analisis Regresi Untuk Penelitian. Edisi I, Cetakan 1, Yogyakarta.

[14] Usman, M, A. Santoso, E and Hidayat, N. 2017. Sistem Pendukung Keputusan Pemilihan Anggota Pengurus Harian Pondok Pesantren Menggunakan Metode Profile Matching. Jurnal Pengembangan Teknologi Informasi dan Ilmu Komputer e-ISSN: 2548-964X Vol. 1, No. 10, Oktober 2017, hlm. 1176-1184

[15] Warmansyah, Julio. "Penerapan Metode AHP untuk Menentukan Kenaikan Pangkat Karyawan di PT METRASAT" Teknois, 2018, doi:10.36350/jbs.v8i2.14. 